

\section{$=$ Contents}

\section{Introchetion}

About Streanns

What Is a Watershed?

Watersheds, Geology, \& Climate 3-4

Features

Stream "Personality"

How Healthy Streams Work

What Shapes a Stream

Stream Types

Permits You'll Need

\section{Acknowledgments}

\section{CoOperative Funding}

Montana Fish, Wildlife $\mathcal{E}$ Parks

Montana Department of Environmental Quality

Montana Department of Natural Resources $\mathcal{E}$ Conservation

Montana Riparian \& Wetland Association

U.S. Environmental

Protection Agency

U.S. Forest Service

Northern Region

\section{Project Sponsors}

Montana Association of Conservation Districts

Montana Department of Environmental Quality

- Constrictions

- Widening

- Entrenchment 27

- Straightening 28

Streambed Disturbance $\quad 29$

Dewatering 30

Methods \& Costs of Streambank 31 Alteration \& Stabilization

\section{A Finual Word}

Stream Words

Credits
CC 1995,1998 by the Montana Department of Environmental Quality. All rights reserved. Printed in the United States of America by Color World of Bozeman, Montana, on recycled paper.

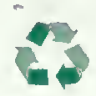

You may reproduce or copy any portion of this booklet after notifying the Montana Department of Environmental Quality. Please acknowledge this publication as the source.

\section{April 1998}




\section{INTIRODUCIION}

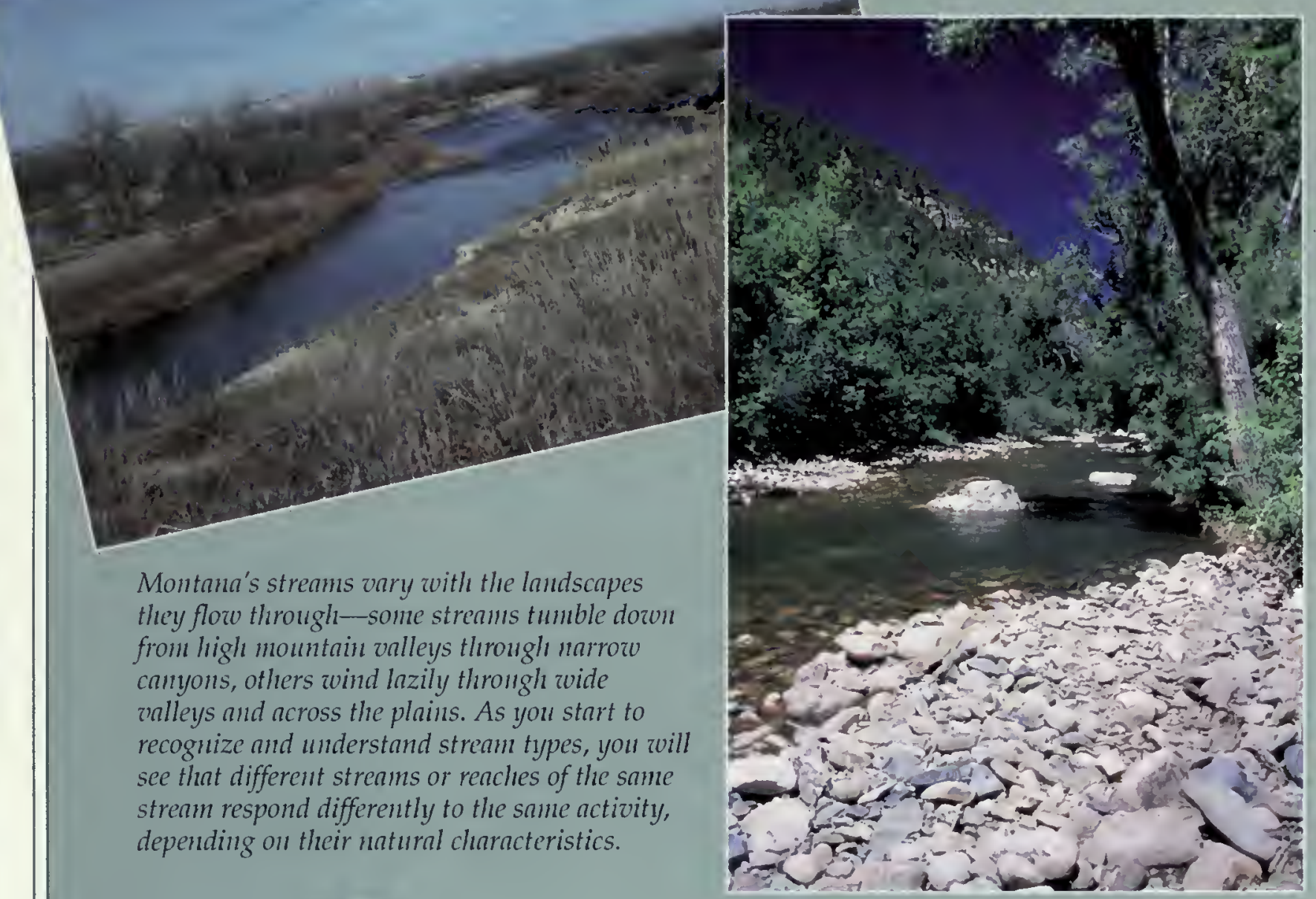

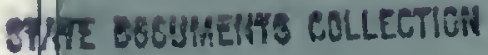

\section{Pin 21 laş}

NTANA UTATE LIBRARY 1515 E. 6th AVE.

HELENA, MONTANA 59520 treams link Montana's mountains and plains, public and private lands, and upstream and downstream neighbors. People can make sound management decisions if they understand how streams work. This guide provides helpful background information for landowners and managers, resource professionals, state and local decision-makers, recreationists, and others interested in streams.

All Montanans are affected by how streams are managed-whether for agricultural, domestic, or industrial uses or for our enjoyment of wildlife, fisheries, or water-related recreation. Flowing water is a shared and limited resource which requires cooperative management among many users and interests. Good stream management makes good Sense. Healthy, stable streams are the most economical and productive for all. In Section One, "About Streams," you'll learn about the characteristics and behavior of healthy streams. Section Two, "About Restoration," discusses your role in management and restoration decisions, what permits you'll need, and which agencies to contact. Section Three, "Working with Streams," focuses on specific examples of stream problems that you might encounter. 


\section{ABOUT STREAMS}

\section{What is a Watershed?}

A watershed is the total land area being drained by a particular stream or river.

Montana has 16 major watersheds (also called river basins), which are pictured belowv. These watersheds contain many, many smaller watersheds.

\section{Montana's Major \\ Watershed Basins}
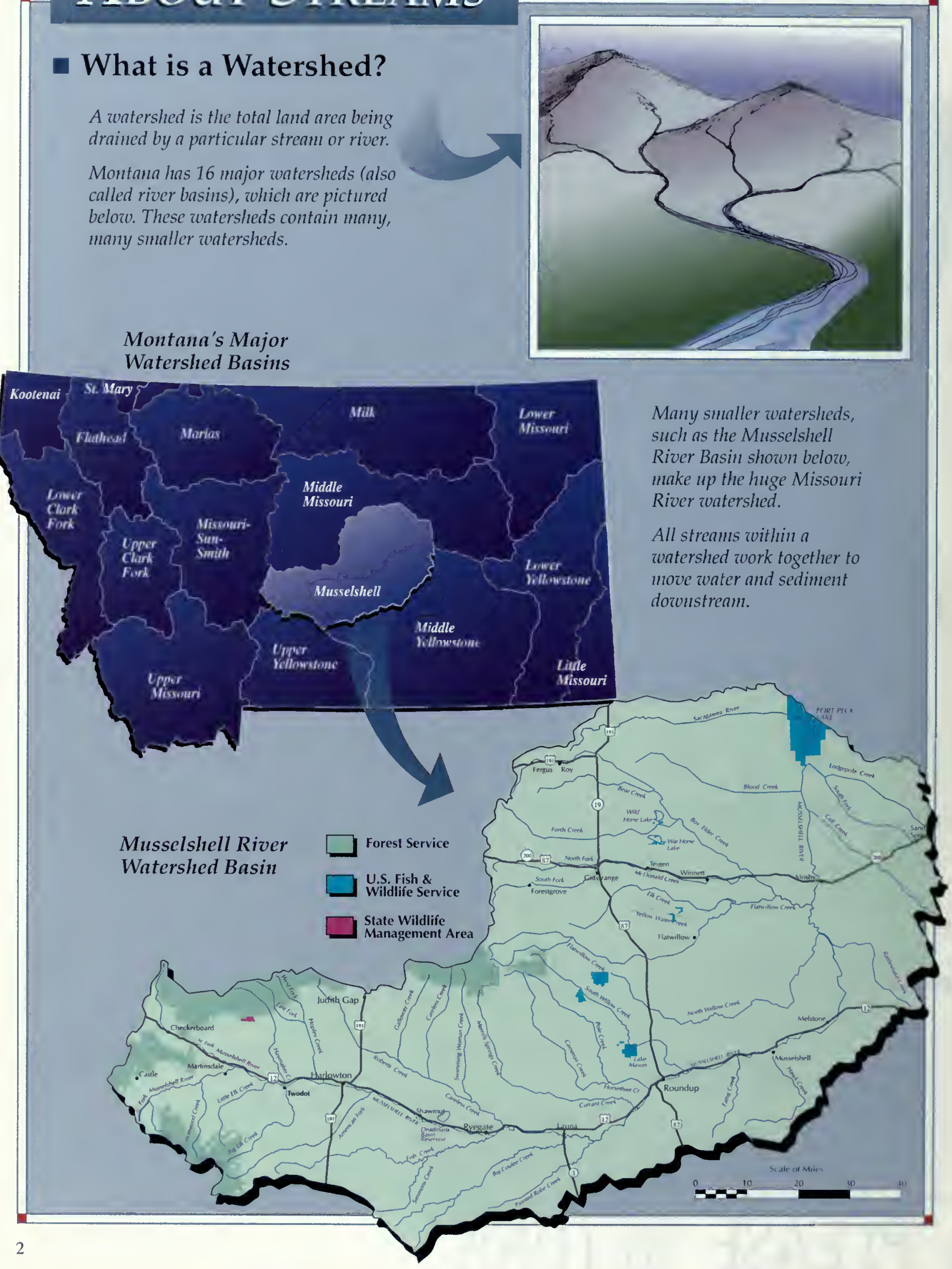


\section{Watersheds, Geology, and Climate}

Stream chamels are formed by the flow of water and the load of sediment they carry. The amount of water and sediment moving through a watershed depends on clintate and geology.

\section{Climate determines:}

- amount of rain and snow, and the timing of runoff

- rate of evaporation

- type of vegetation

- rate of groundwater recharge

- rate of erosion

- how quickly bedrock weathers to soil

\section{Geology determines:}

- rate of erosion

- potential for sedimentation

- stream bank material

- permeability and porosity of soils

- aquifer depth and recharge rate

- water chemistry and biological productivity

Precipitation in Montana falls unevenly-most falls in the western third of the state, west of the Continental Divide. Because of this, more water flows ont of the state in the Clark Fork River than in the Missouri River, which collects water from the enstern two-thirds of the state.

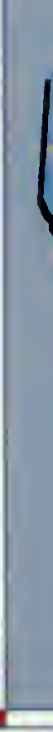

Average Annual Precipitation

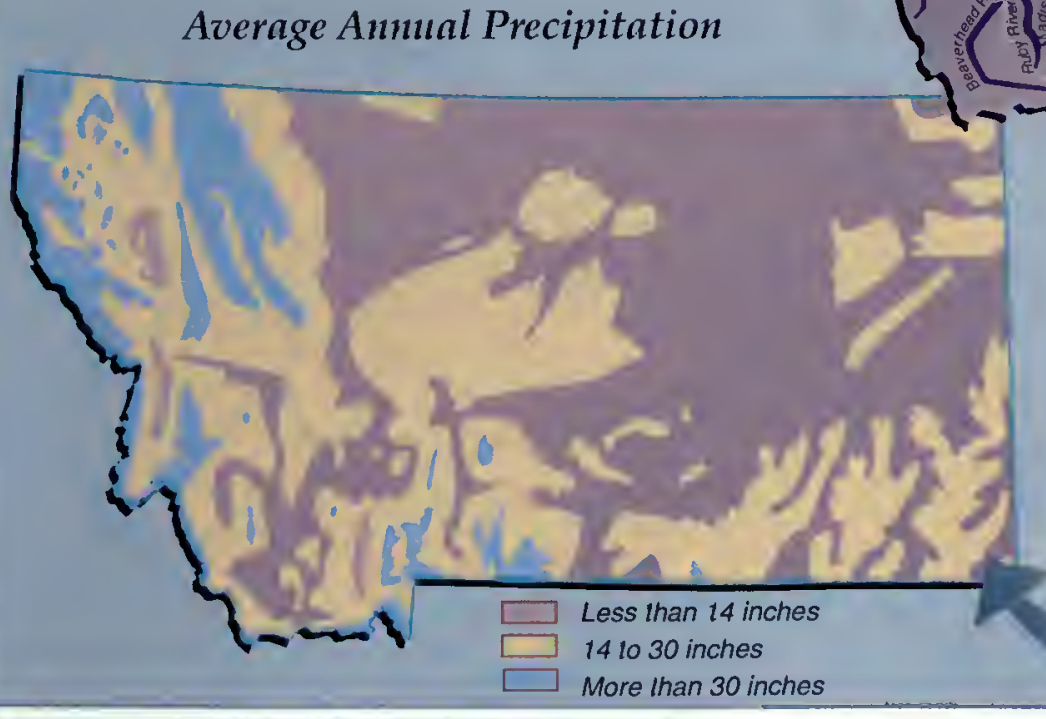

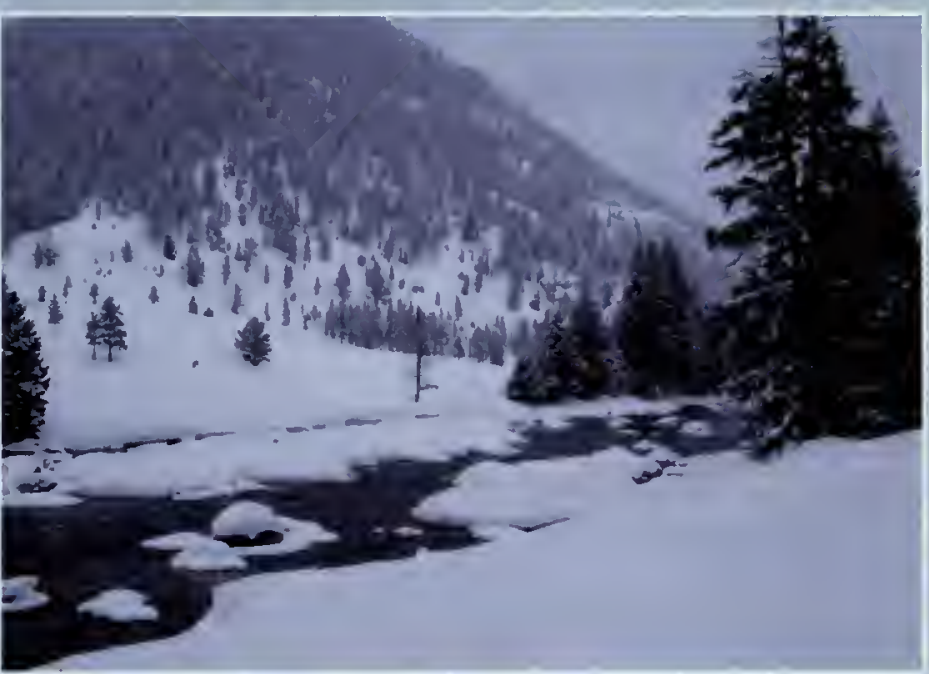

Peak flow, the greatest flow in a stream, typically occurs in western Montana during late spring and early summer when snow melts in the mountains. In eastern Montana, some streams experience high flows after intense rainstorms in spring and summer.

Base flow, the lowest flow in a stream, typically occurs in western Montana from late summer through the winter. Flows may go entirely below ground during dry periods.

\section{Average Anumal Runoff}

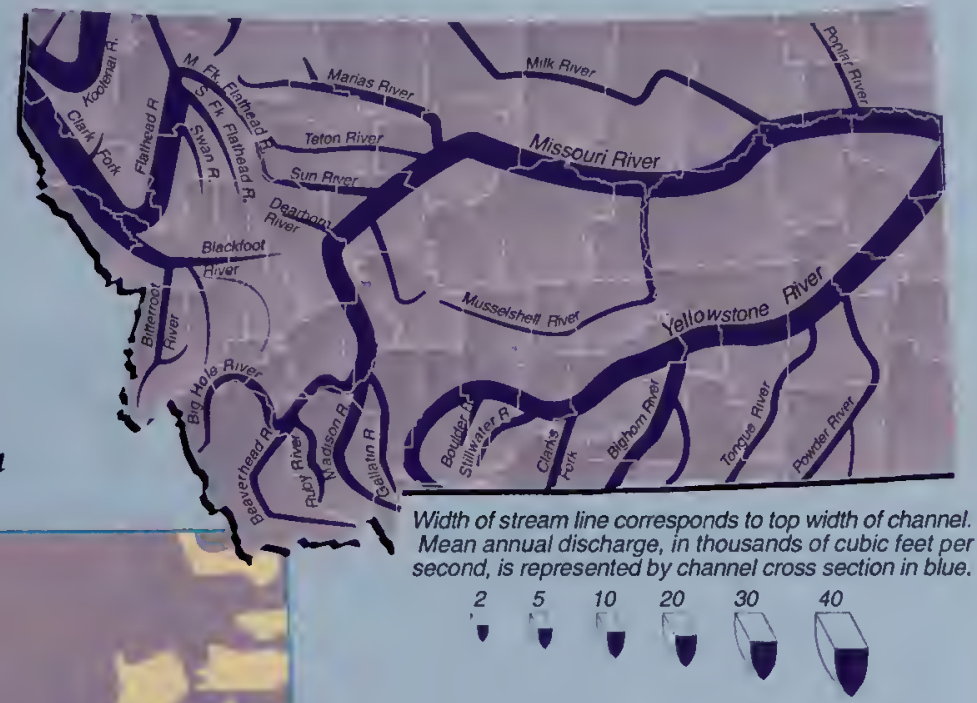

Forested, mountainous watersheds in northwestern Montana receive 60 to 100 inches of precipitation per year and have more perennial streains; grassy plains watersheds of enstern Montana, which receive 8 to 12 inches of precipitation, have more intermittent and ephemeral streans. 


\section{ABOLTLSTREAMS}

\section{Watersheds, Geology, and Climate}

Montana's streams are as diverse as the landscapes through which they

flow-from the forested mountains to the grassy plains.

\section{$W_{\substack{\text { hena } \\ \text { stream }}}$ flows}

through a steep, narrow valley, it runs relatively straight and fast, cascading and scouring out pools.

Some streams flow slowly through wide, flat valleys. Wetlands and riparian areas form along the banks and occupy floodplains, creating rich streamside habitat. Stream banks are of finer-textured soils, hold more water, and may support a greater diversity of vegetation than high mountain streams.
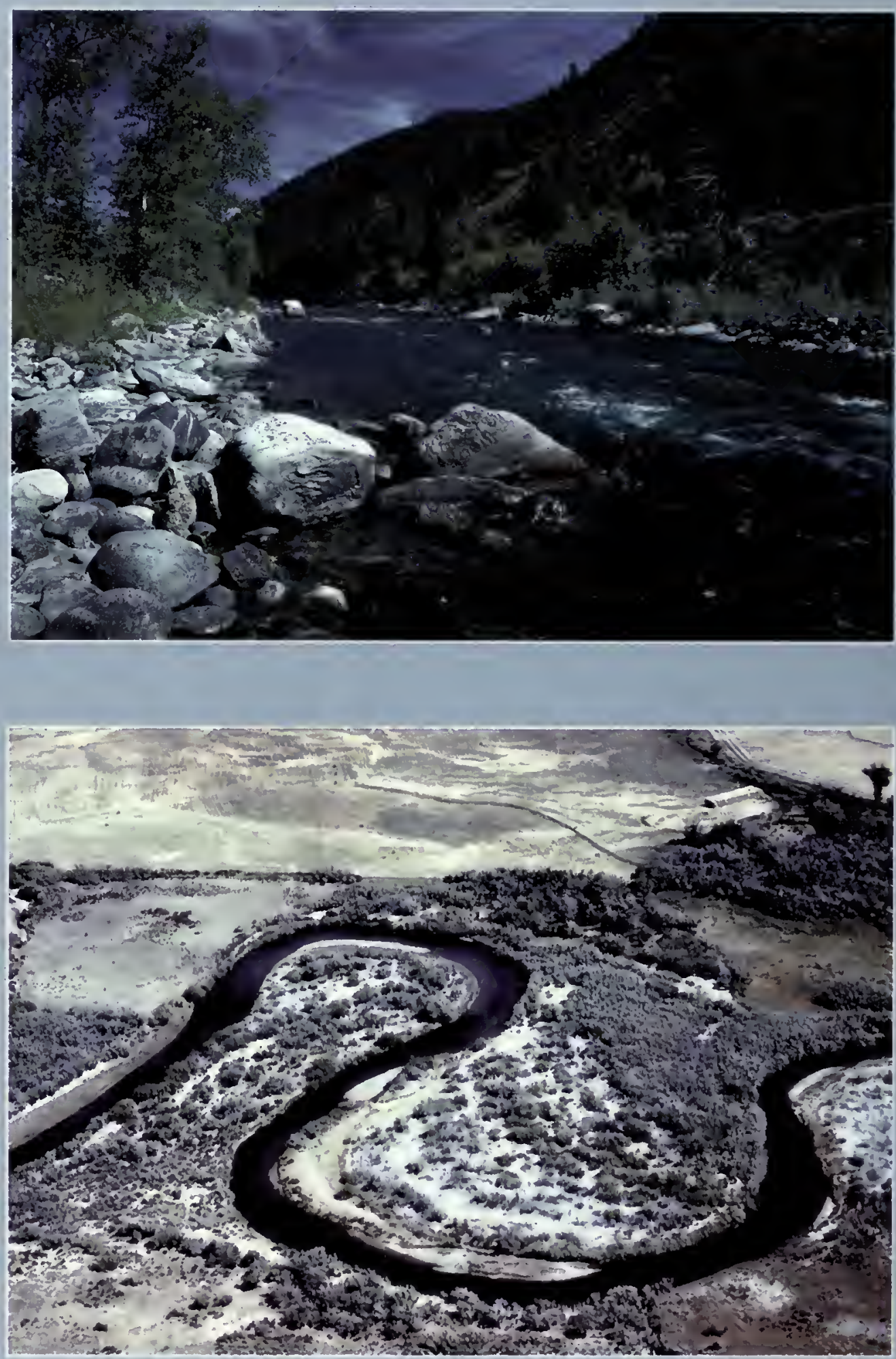
- Features

Components of a Healthy Stream System

- stable stream channel

- active floodplain

- groundwater
- healthy riparian (streamside) vegetation

- high quality waters

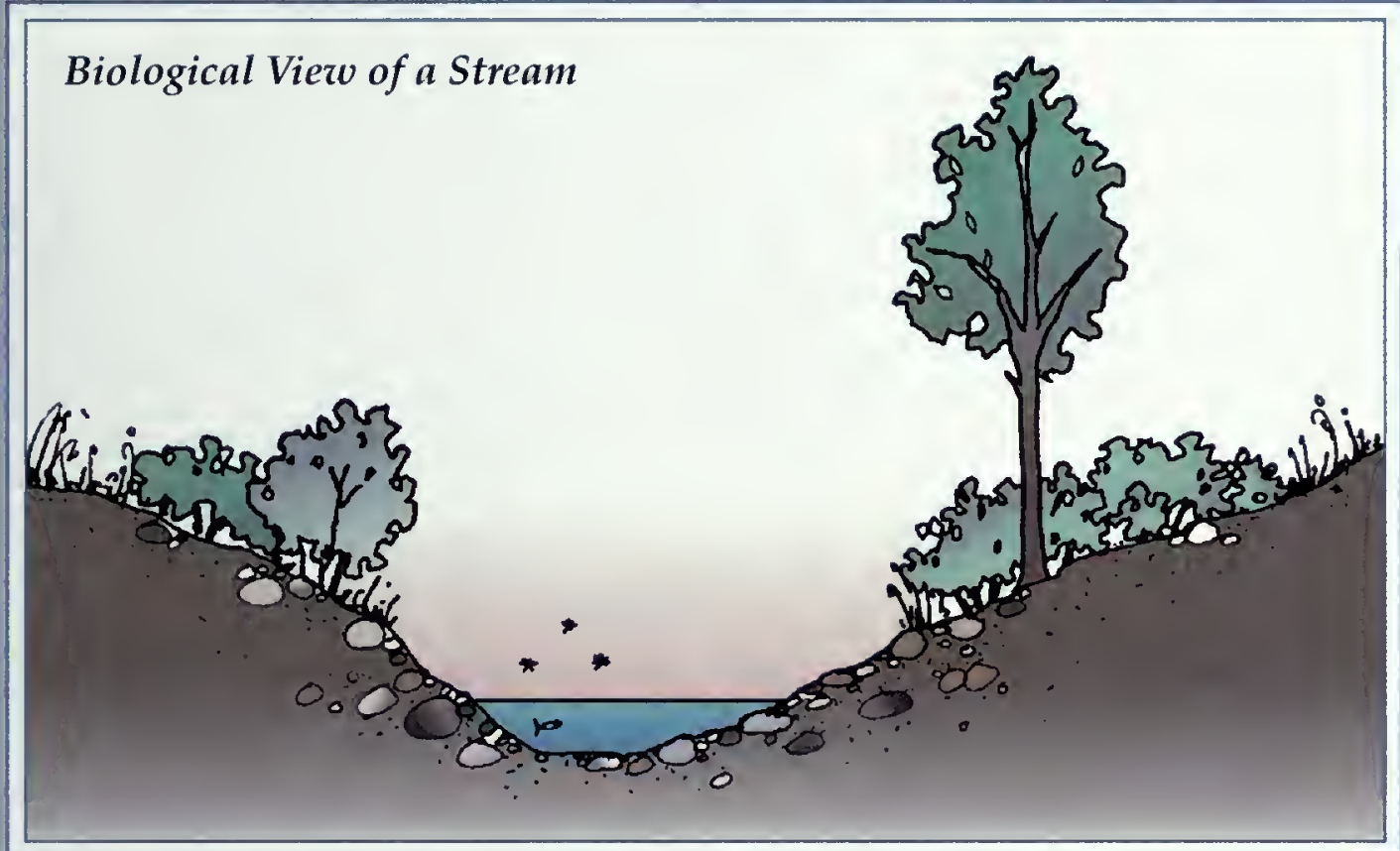

Physical View of a Stream

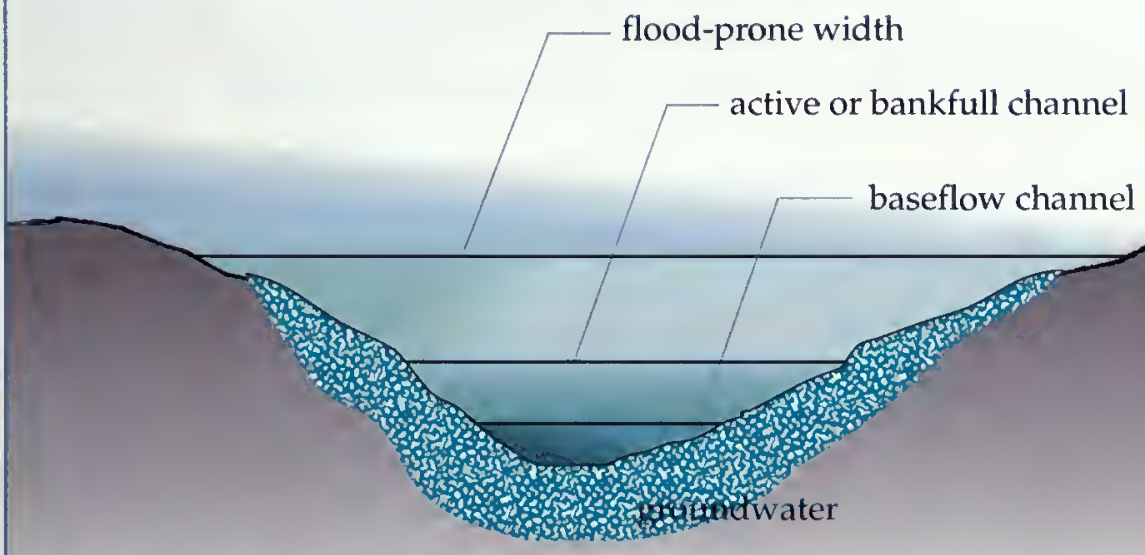




\section{ABOLILSTREAWTS}

\section{Features}

Groundwater is the water that seeps through the spaces between soil particles and flows into aquifers.

Aquifers are saturated zones of sand, gravel, or fractured bedrock underlying the valley.

Porosity is the volume of the spaces or pores between particles in an aquifer. It varies with the type of material present and determines how much water the aquifer can hold.

Permeability is the rate of water movement through the soil or aquifer. It is much faster in materials with large pores, such as gravels and sand, than in materials with small pores, such as clays.

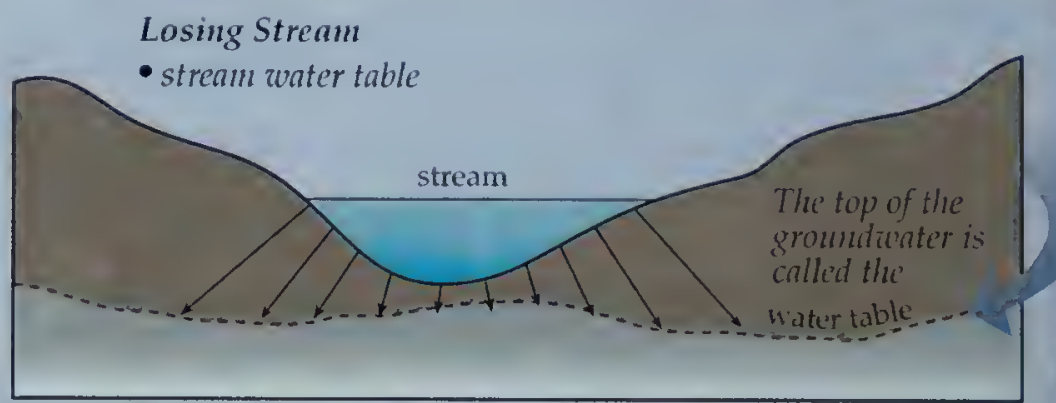

During dry periods, groundwater may RECEIVE water from the stream.

Gaining Stream

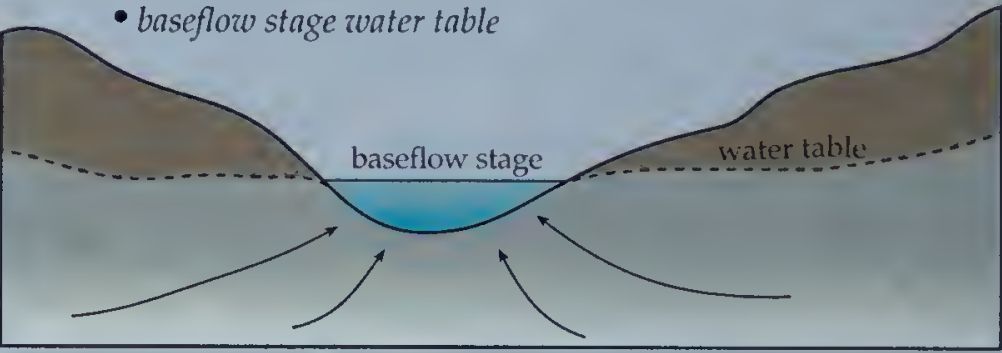

During wet periods, groundwater ADDS water to the strean.

Gravity is the driving force behind rivers, causing water to flow downhill, to seep into streams when the water table lies above the streambed, and to seep into the ground.

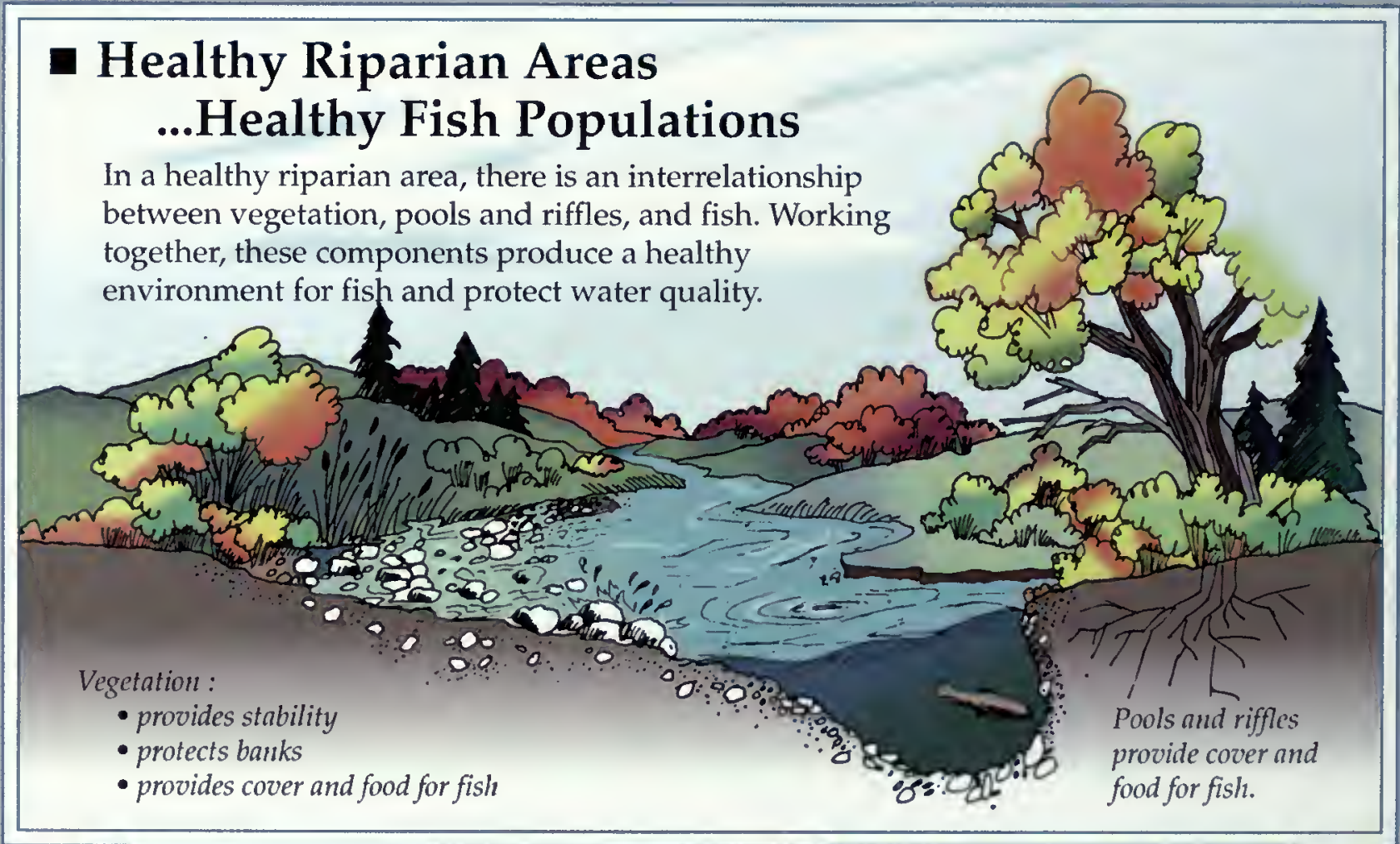




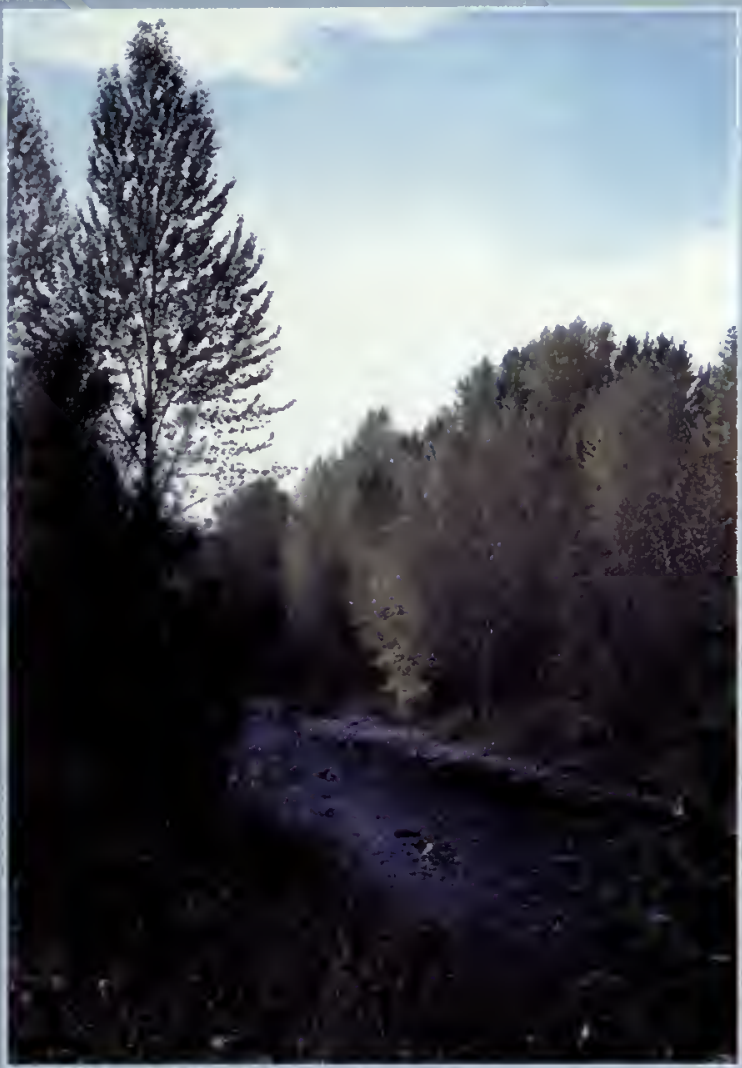

\section{Floodplains}

Flooding is a natural stream process. A floodplainland next to a stream where water overflows during floods-is an important part of the stream system.

\section{The Role of Floodplains}

- Spread out and slow flood waters, reducing their erosive force.

- Slow water enough so it can seep into soil, recharge aquifers, and slowly return to stream.

- Filter sediment that settles from the water, building deep, fertile soils.

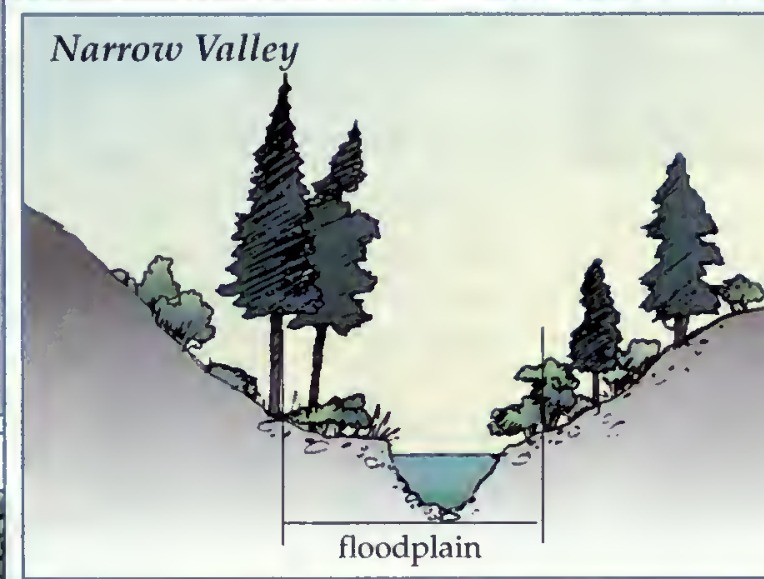

Wide Valley

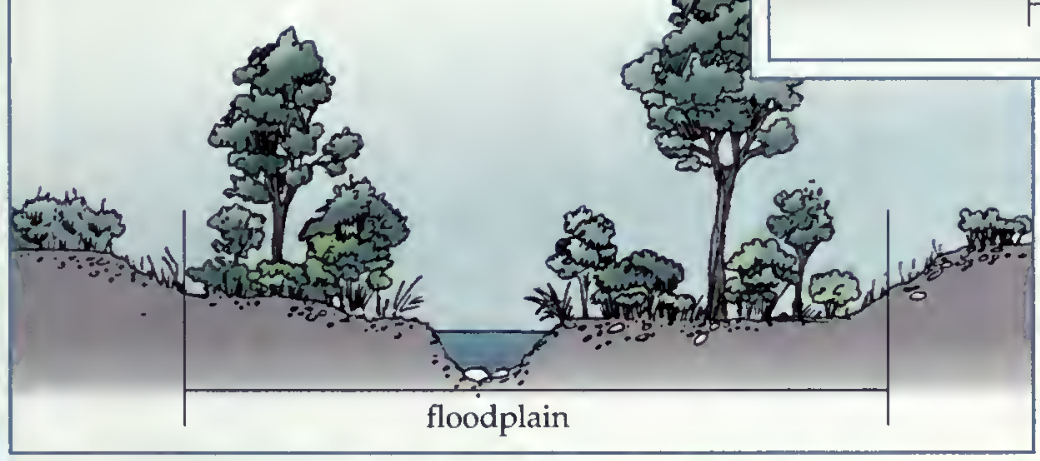

The Biological Richness of Riparian Areas and Streanside Wetlands

1. Riparian areas contain a diversity of plants.

2. They provide wildlife with:

- corridors for migration

- cover from weather and predators

- breeding, resting, nesting, and foraging areas

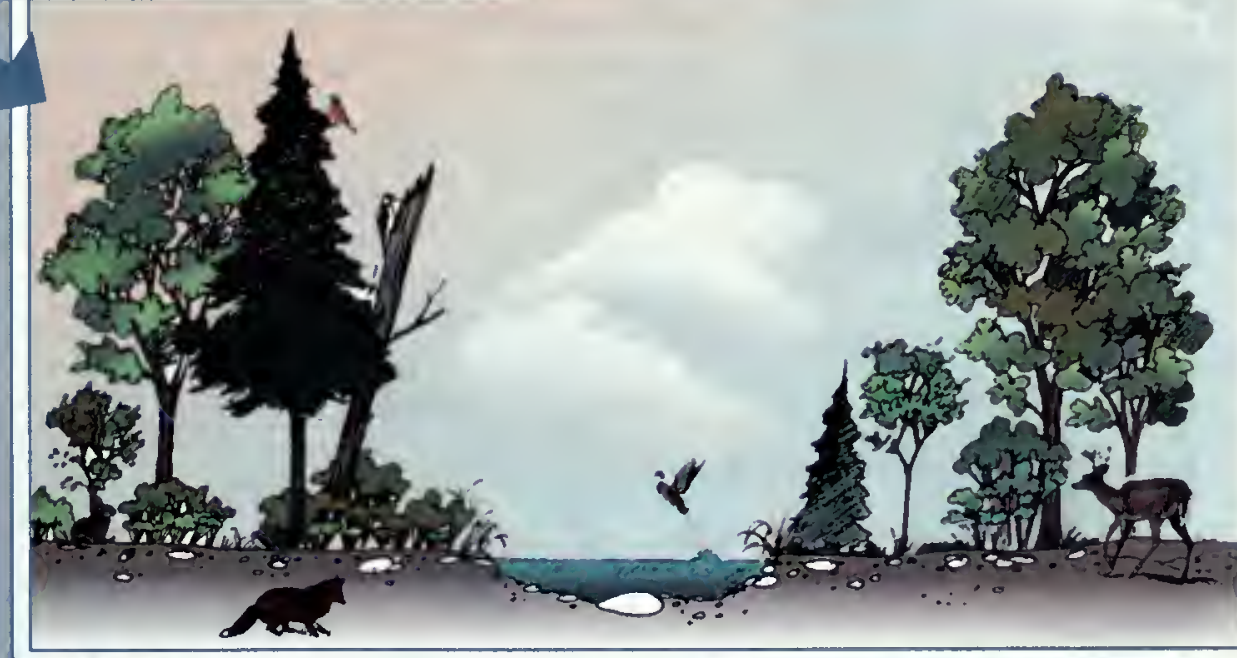




\section{ABOLILSTRELMLS}

\section{What's Your Stream's Personality?}

These clinacteristics determine many stream

types, each with its own "personality."

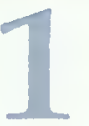

\section{What's the most common material making up the channel and bank?}

\section{Silt/Clay smooth}

between fingers

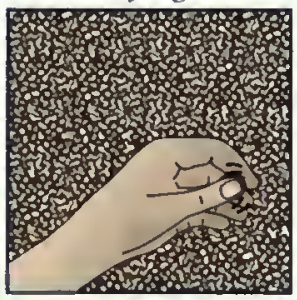

SAND feels gritty

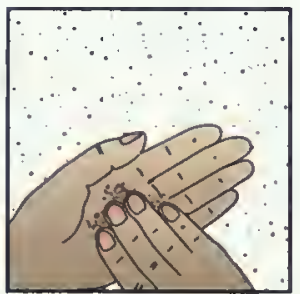

Gravel fits in hand

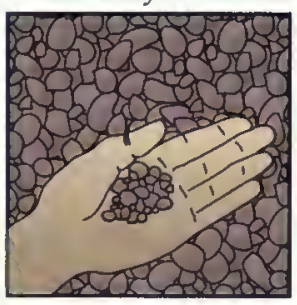

Cobble

you can stand on

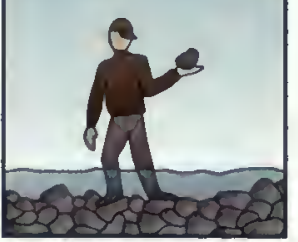

BOULDER

you may have to climb over

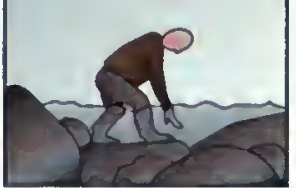

Channel and bank materials are critical characteristics of a stream.

They determine:

- sensitivity to disturbance and potential for erosion

- recovery potential

- ability to support vegetation

- role of vegetation in stabilizing stream channels

- amount of channel roughness to slow stream flow and reduce stream energy

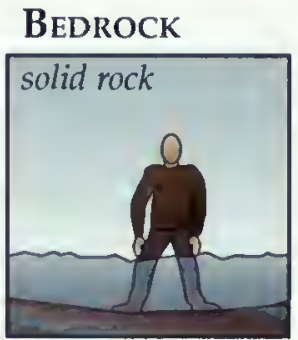

1 Channel and bank materials

2 Simnosity

3 Channel gradient

4 Floodplain

5 Channel shape By understanding the combination of characteristics that make up your stream's personality, you can determine appropriate managentent practices. Changing aniy of these characteristics without careful planning can cause mumanted clinnges in the stream (see pages 14-17 and 22-30).
Other important stream characteristics not illustrated here:

6 Flow timing and alnount

7 Amount and size of sediment

\section{How simuous is the channel?}

Sinuosity refers to the amount of curvature in a stream channel. The increased length of a highly sinuous channel helps to dissipate stream energy. Shorter and straighter channels possess more stream energy and erosion potential.

\section{straight \\ slightly sinuous \\ highly sinuous \\ (nieandering)}
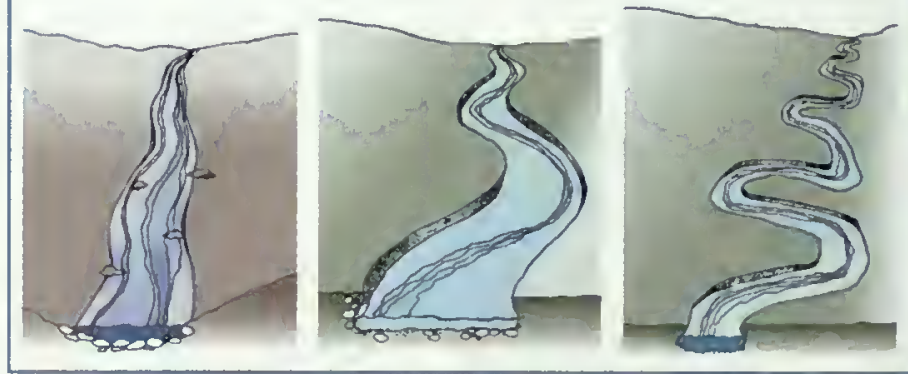

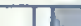

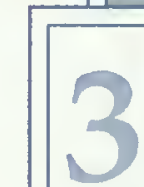

\section{What is the gradient of the channel?}

The steeper the channel gradient, the greater the water velocity and potential for erosion.

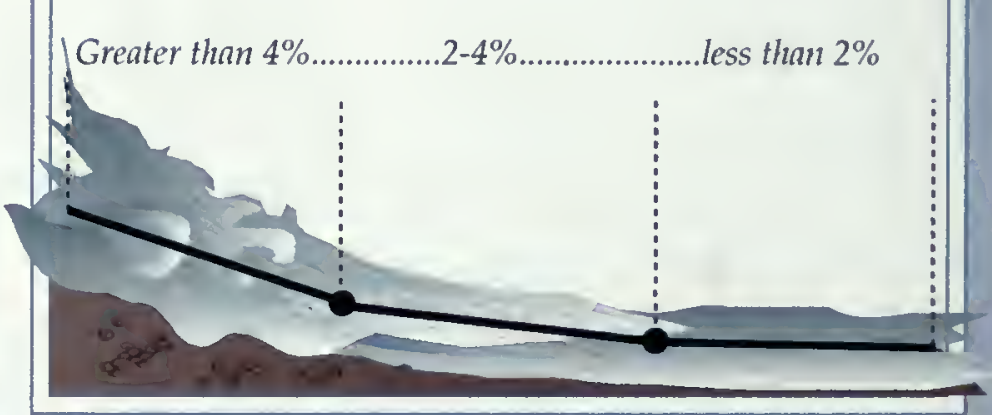




\section{Is a functioning floodplain present?}

Does your stream overflow its banks every few years? If not, the stream may be changing because of alterations in the watershed. Without a floodplain, the stream's energy is concentrated in the channel during flood flows. This increased energy may either downcut the channel or erode the banks.

To determine the edge of the bankfull channel, which is the beginning of the floodplain, look for:

- top of point bar

- change in vegetation

- slope break

- change in particle size of bank material

- undercuts in the bank

- stain lines or lower extent of lichens on boulders

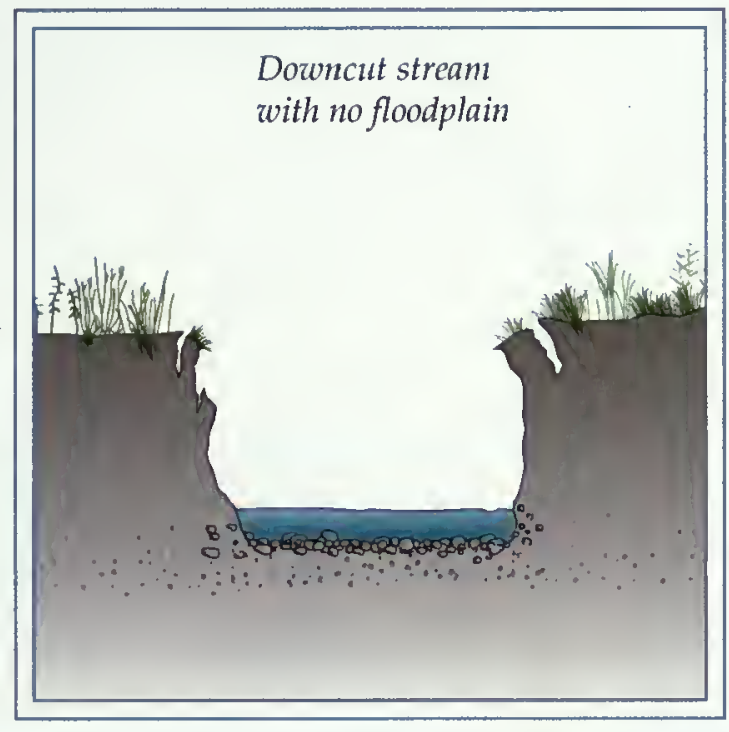

All of these characteristics influence the personality of your stream under natural conditions. Stream types may be changed by our alterations and activities.

\section{Stream with functioning floodplain}

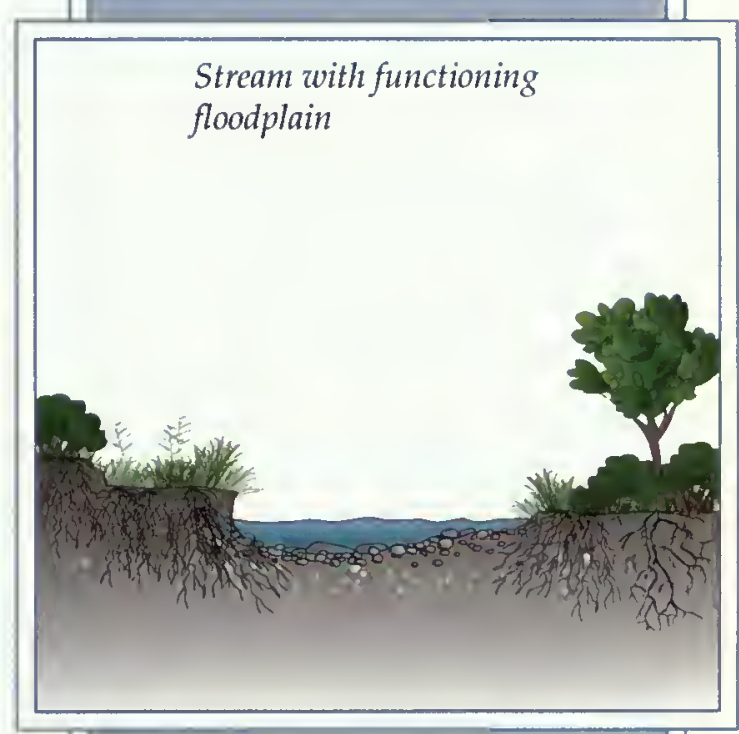

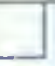

What is the channel shape? Channel shape is mostly influenced by:

- quantity of water

- amount and size of sediment

- type of bank and bed material

- gradient/valley slope
- amount and type of vegetation and its associated root mass

- human activities that directly alter channel or watershed
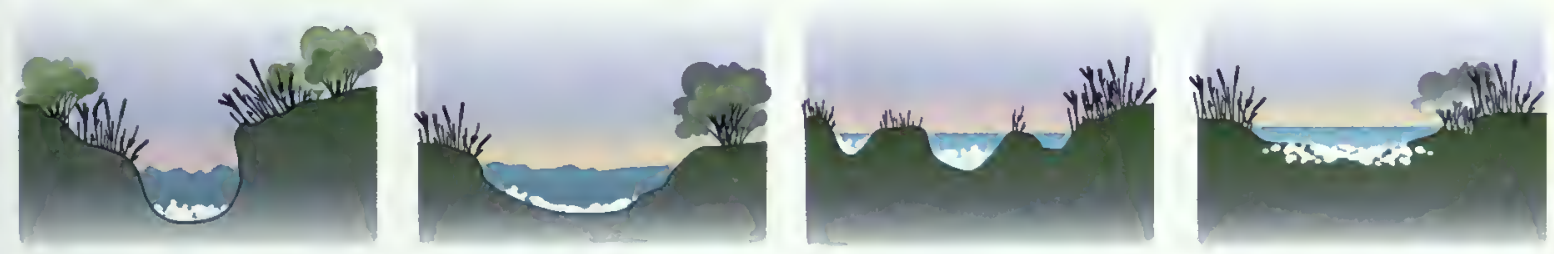

Common channel shapes 


\section{¿LBOLLLSTREALS}

\section{- How Healthy Streams Work}

Now that you know about the features and characteristics of streams, let's think about how a healthy stream works:

- What is it trying to accomplish?

- How does it maintain a balance of water and sediment?

- How does it form a shape?

Streans begin when water accumulates and moves through a watershed. To simulate this action, pile dirt into a hill. Begin squirting water on the hill; you'll see that a stream soon forms. You've eroded a channel in the dirt and created a stream full of energy. Based on the stream's characteristics (see pages 8-9), the stream will use that energy to accomplish two tasks:

- move water

- carry sediment
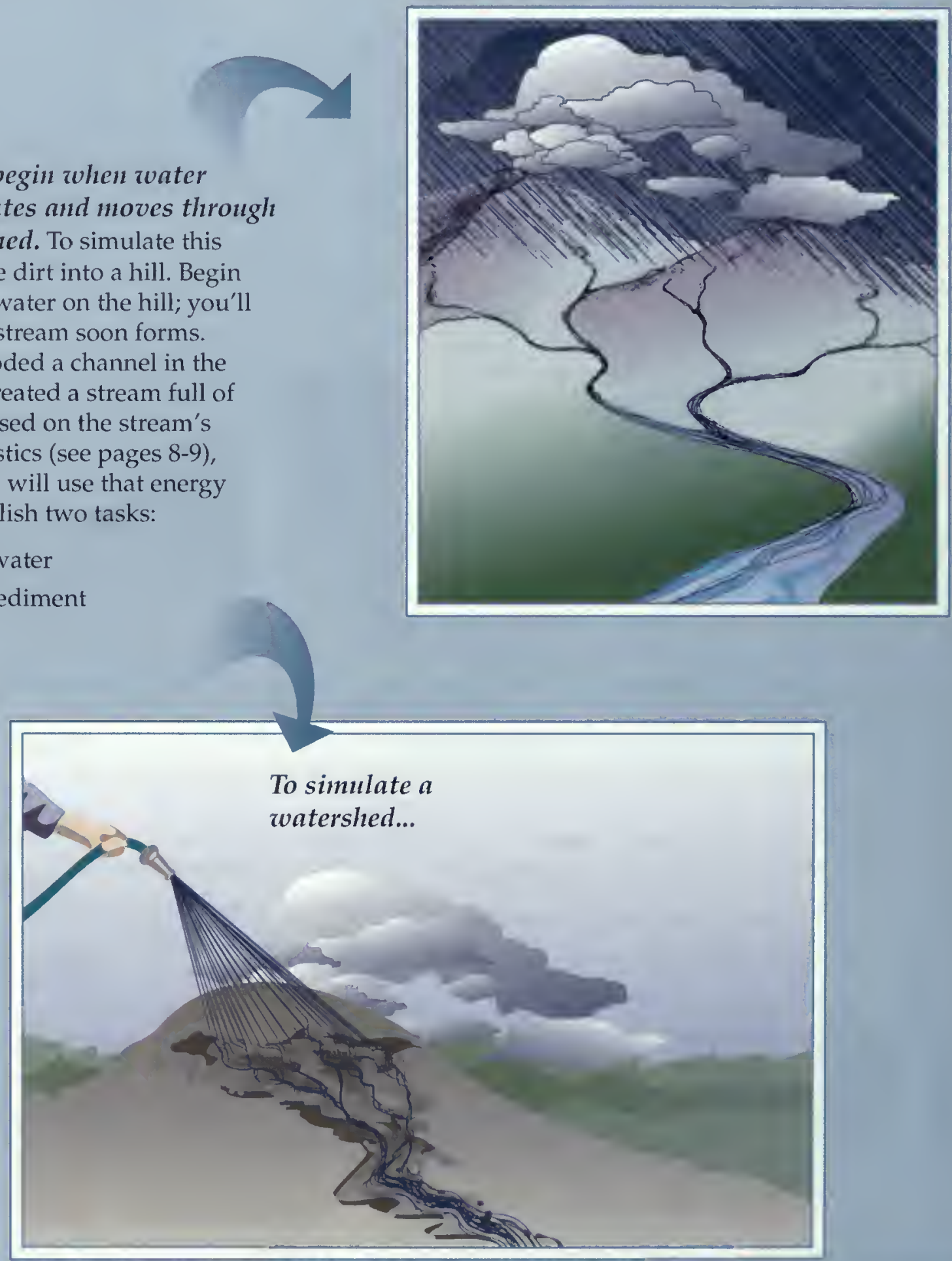


\section{- Keeping the Balance}

In any given reach, a strean constantly adjusts itself.

It is balancing the amount of water and gradient of the

chamel, and the amount and size of sediment.

Any disturbance, either natural or human-caused, will alter this balance. Our activities-such as modifying streams, diverting or adding water, building in floodplains, or removing vegetation-can limit a stream's ability to maintain a balance. An unbalanced stream is an unhealthy stream.

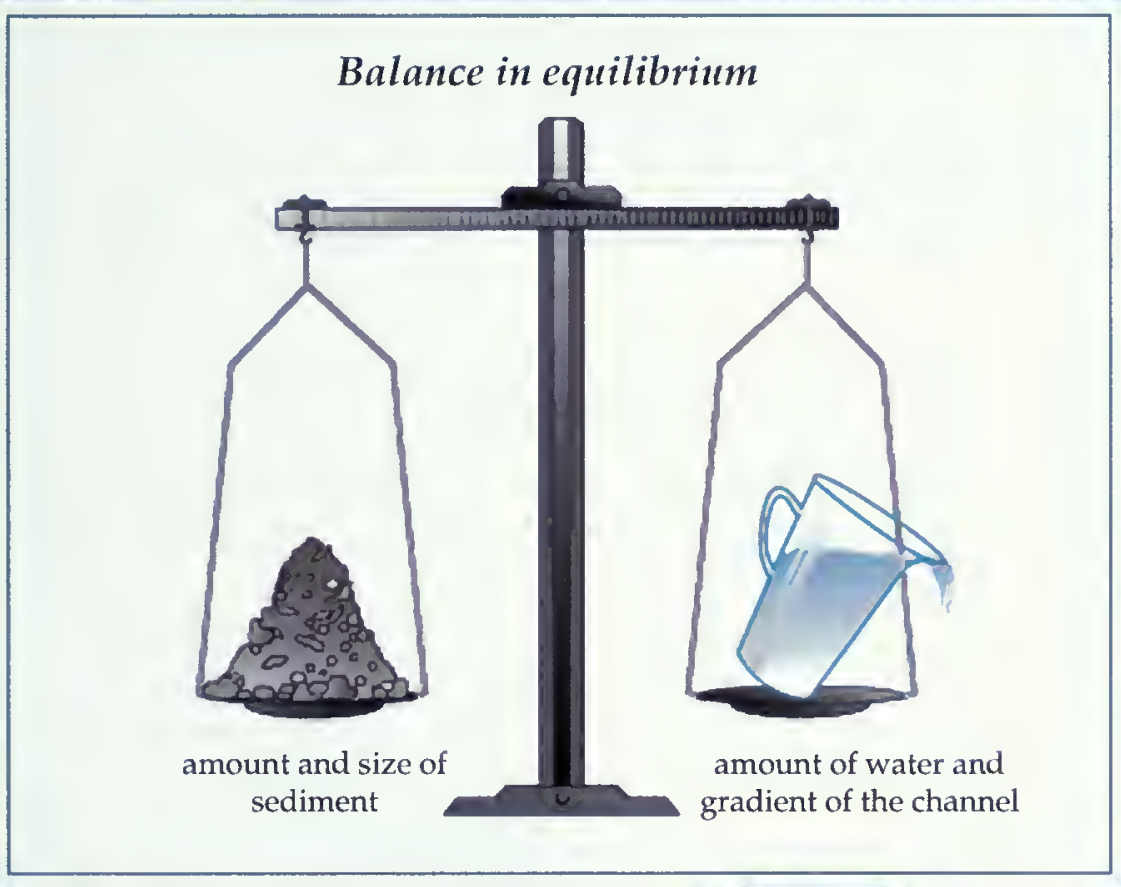

\section{Erosion Isn't Always Bad}

We often think of erosion as the culprit that degrades streams, but erosion is a natural process. A healthy stream bank may erode a small amount each year. Erosion becomes destructive to streams when it increases above the normal rate. Then it takes land azvay from wildlife and agriculture, and reduces the water quality that fish and other aquatic life need. (You'll find more information about this under "Floodplains" on page 7; see also page 24.) 


\section{ABOLLLSTRELMLS}

\section{- What Shapes A Stream?}

As streams move through watersheds, their appearance, shape, and energy change as local conditions change. (Typical types are shown on pages 14-17.) A stream may begin as a rush of water over rocks on a steep slope. Further down the watershed, it may empty onto a wide, flat valley where soft soils erode easily. The stream will migrate across the valley while maintaining its channel shape, gradient, and sinuosity.

\section{Forming Meanders}

Shifts of energy in a stream will also shift the sediment. When the energy core is against the outside bank (see box 3 , next page), it erodes sediment and deposits the material downstream on the inside bend in a point bar. This natural process forms meanders in streams with low gradient.

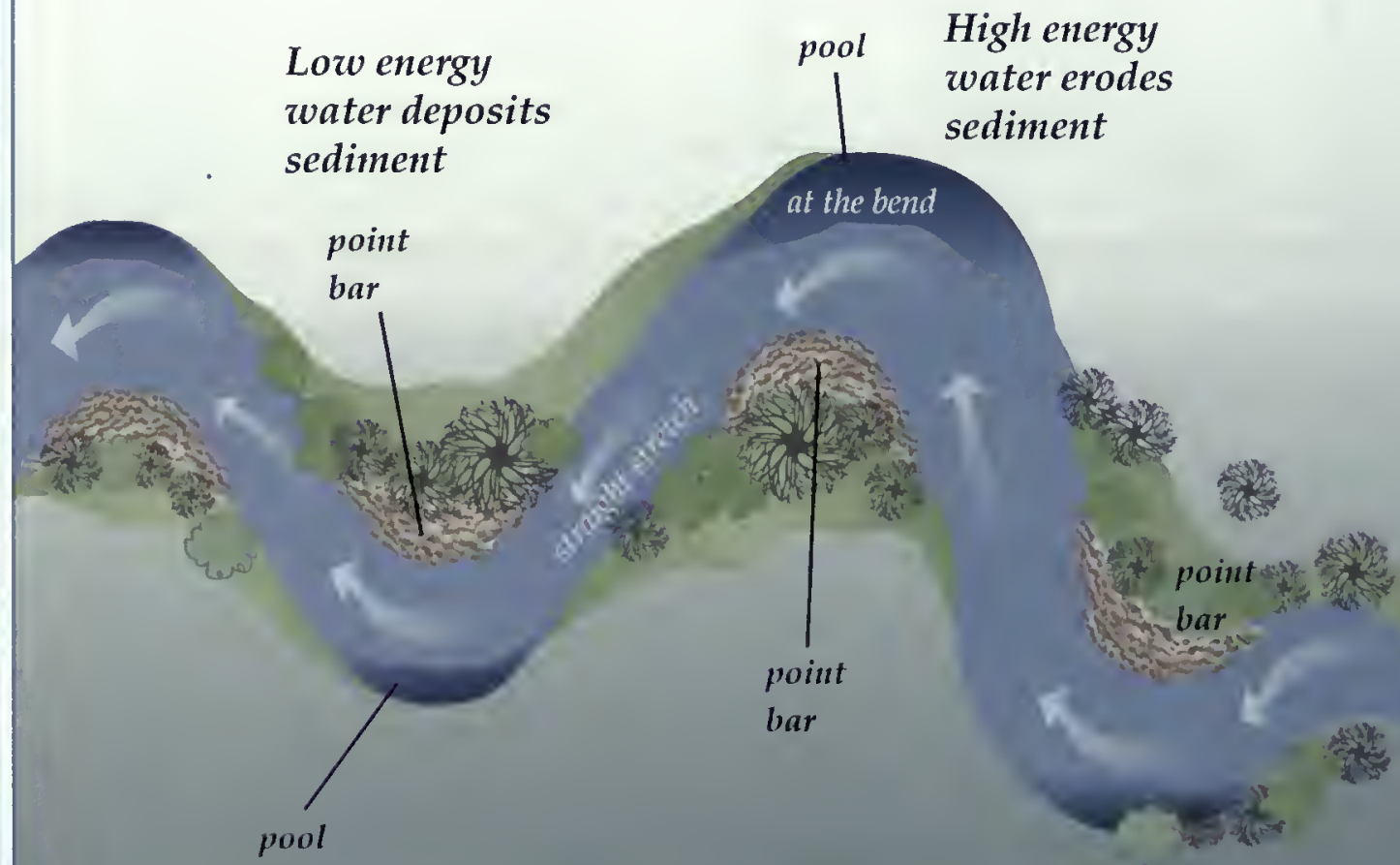




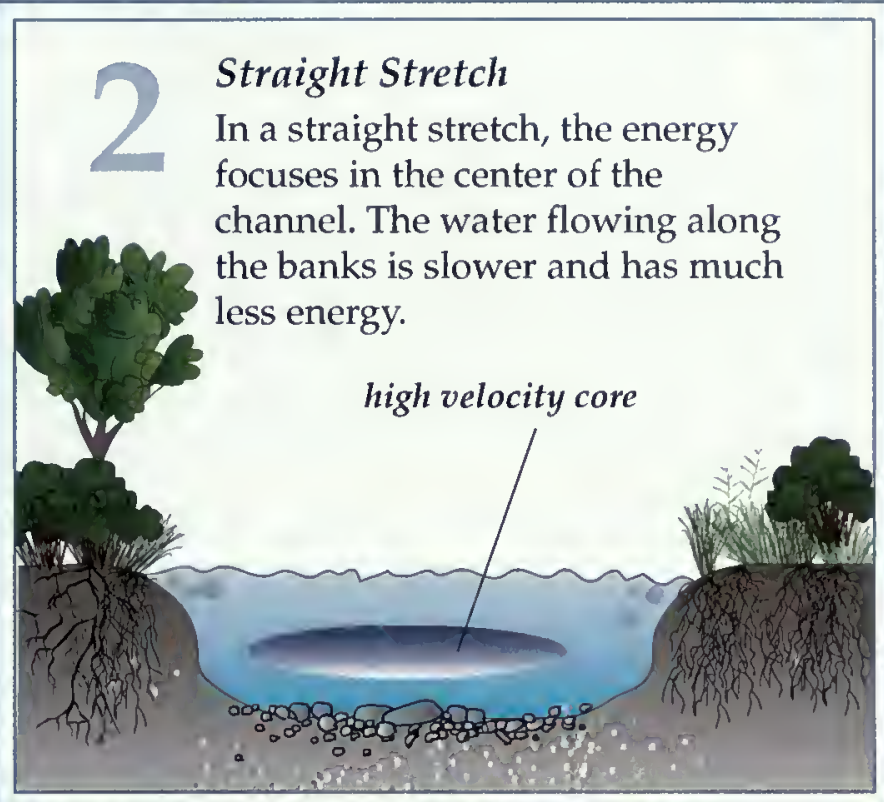

Meandering stream channels naturally migrate over timeand you need to allow plenty of room for this migration. Avoid building near a stream, and always consider the floodplain to be part of the stream. Don't build there!

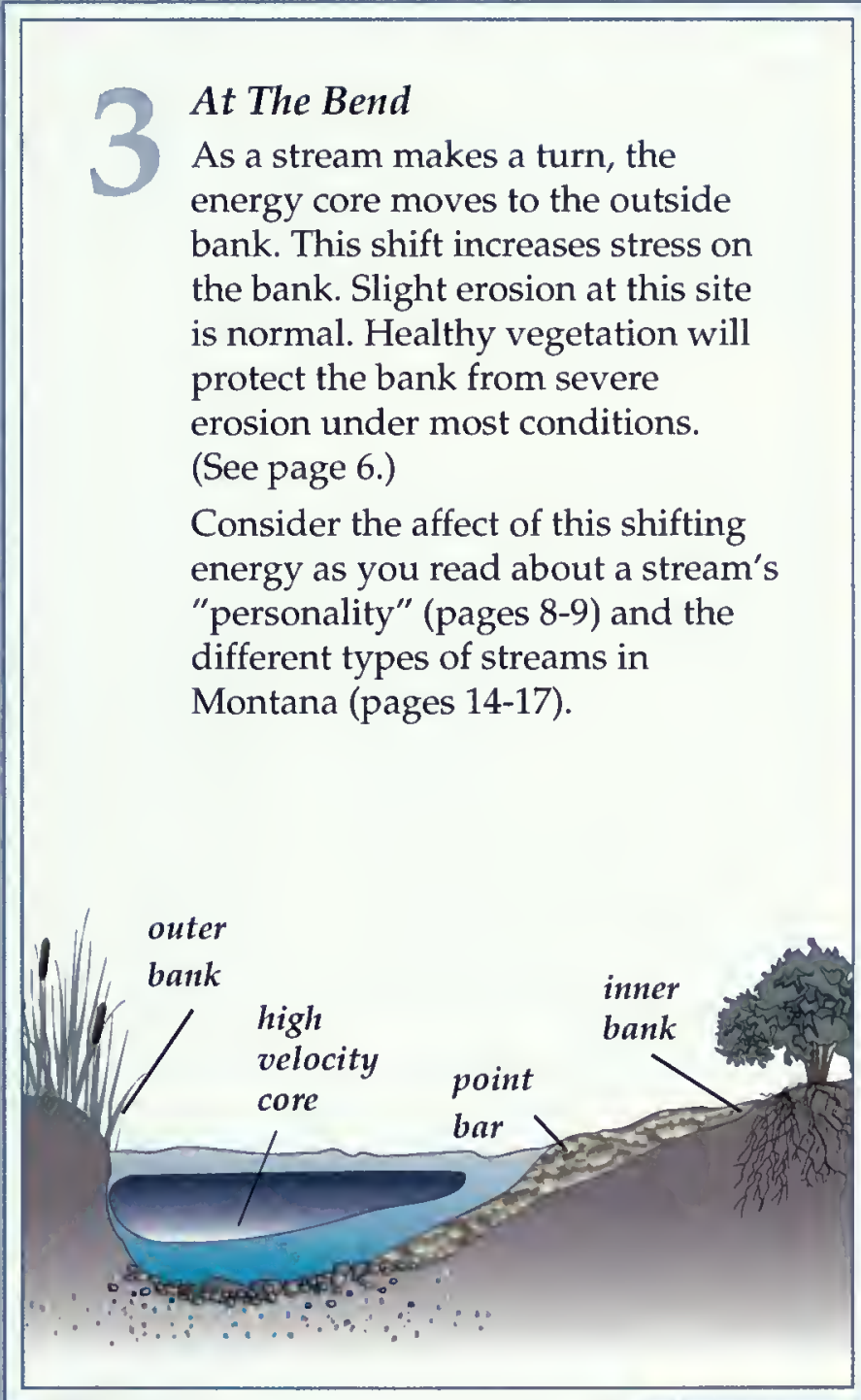




\section{ABOLLLSTREAWS}

- Healthy Stream Types

Common in Montana

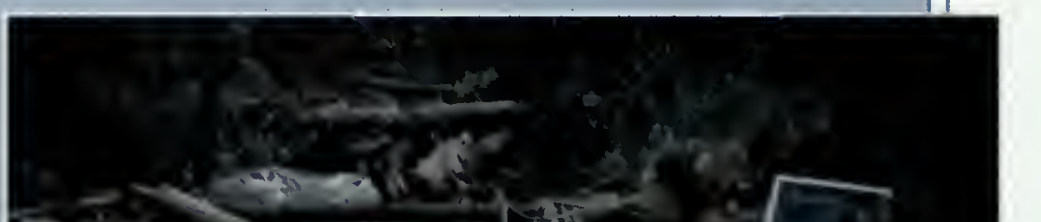

Mountain Stream

- steep slope (greater than 4\%)

- V-shaped valley

- vertical erosion (little horizontal)

- narrow floodplain and riparian area

- narrow, deep channel

- straight to slightly sinuous

- often a series of descending pools

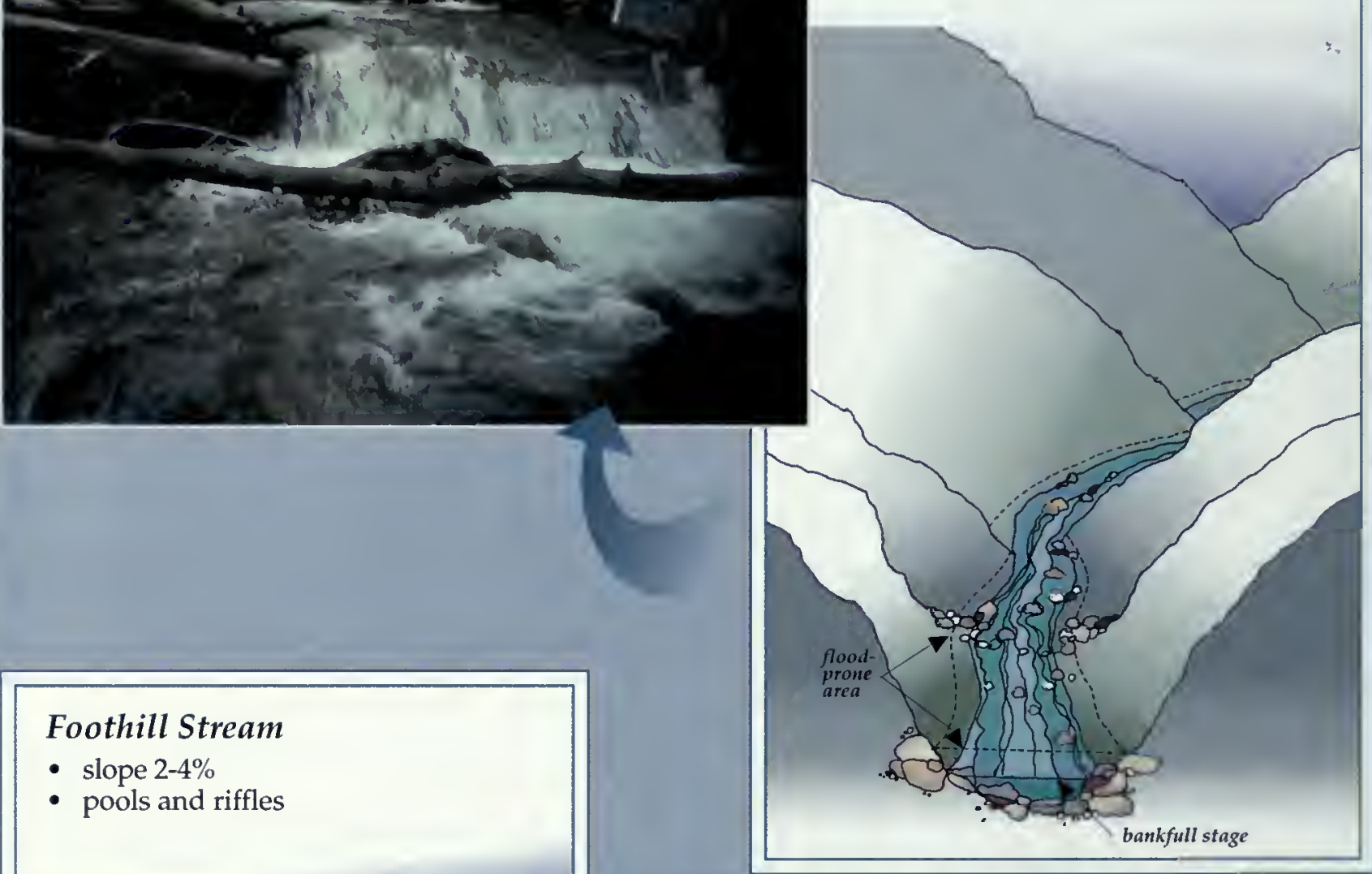

slope $2-4 \%$

pools and riffles

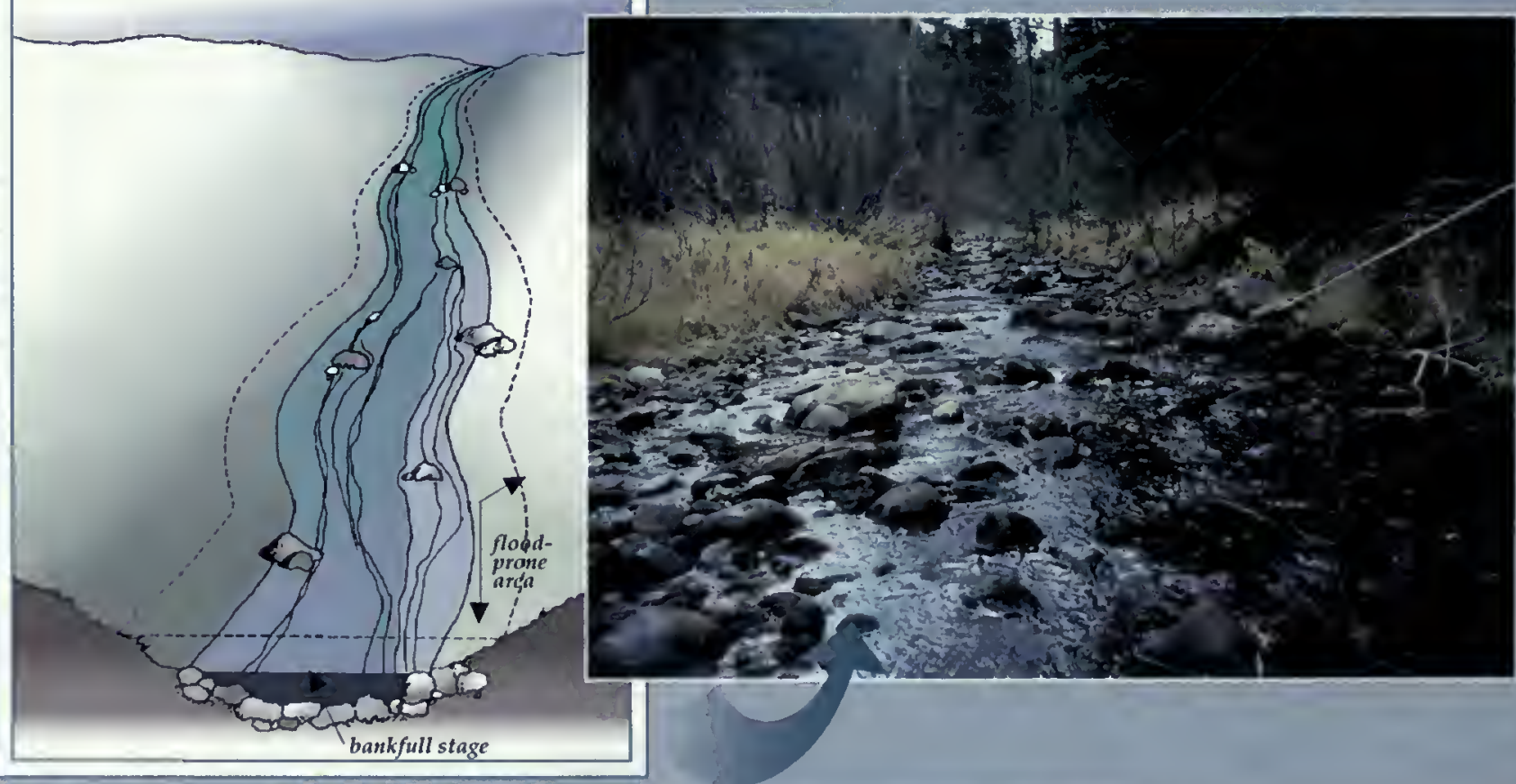




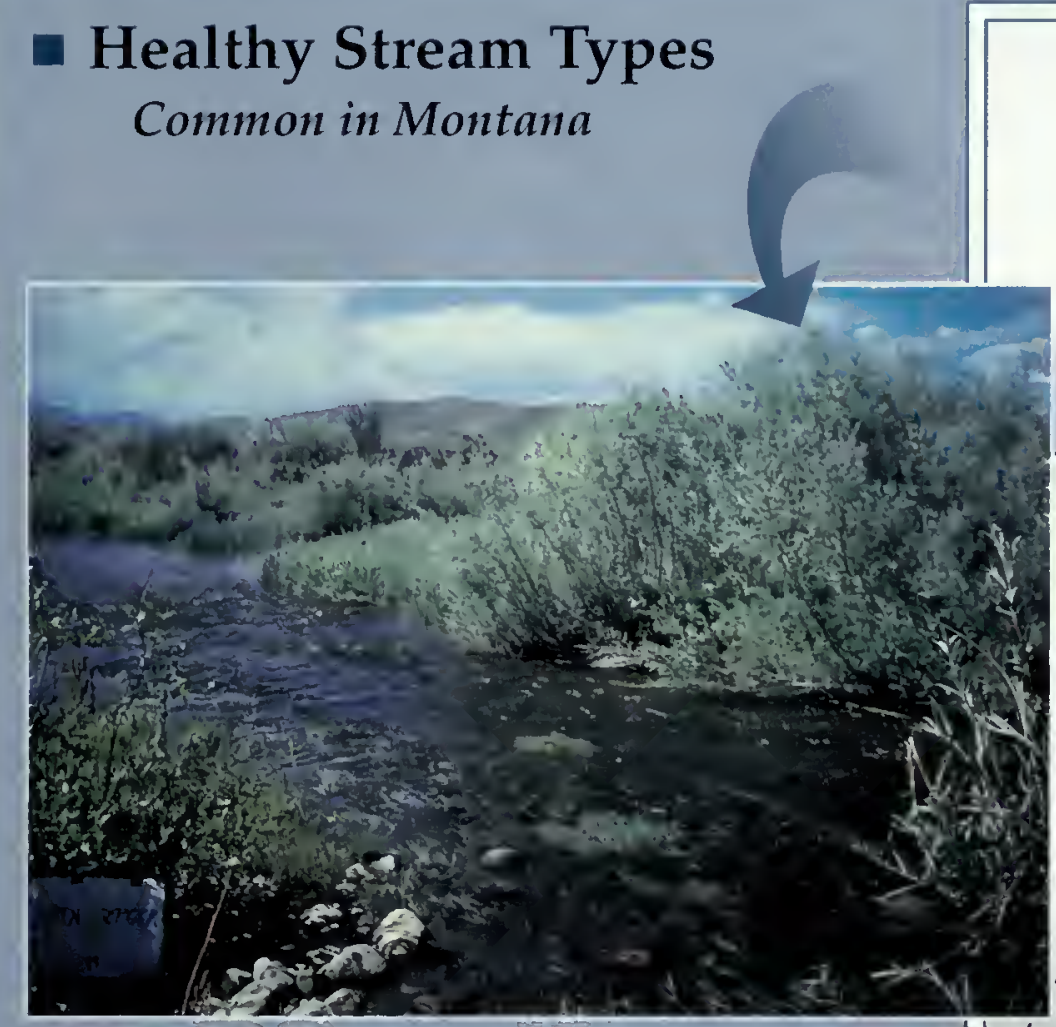

Wide Valley Bottom Stream

- slope less than $2 \%$

- point bars, riffles, pools

- flood flows spread over broad floodplain and riparian area

- sinuous

- wide, shallow

- horizontal (lateral) erosion

\section{Meandering Meadow Stream}

- slope less than $2 \%$

- flat-bottomed valley

- narrow, deep, sinuous channel

- little sediment load

- accessible floodplain

- well-vegetated banks
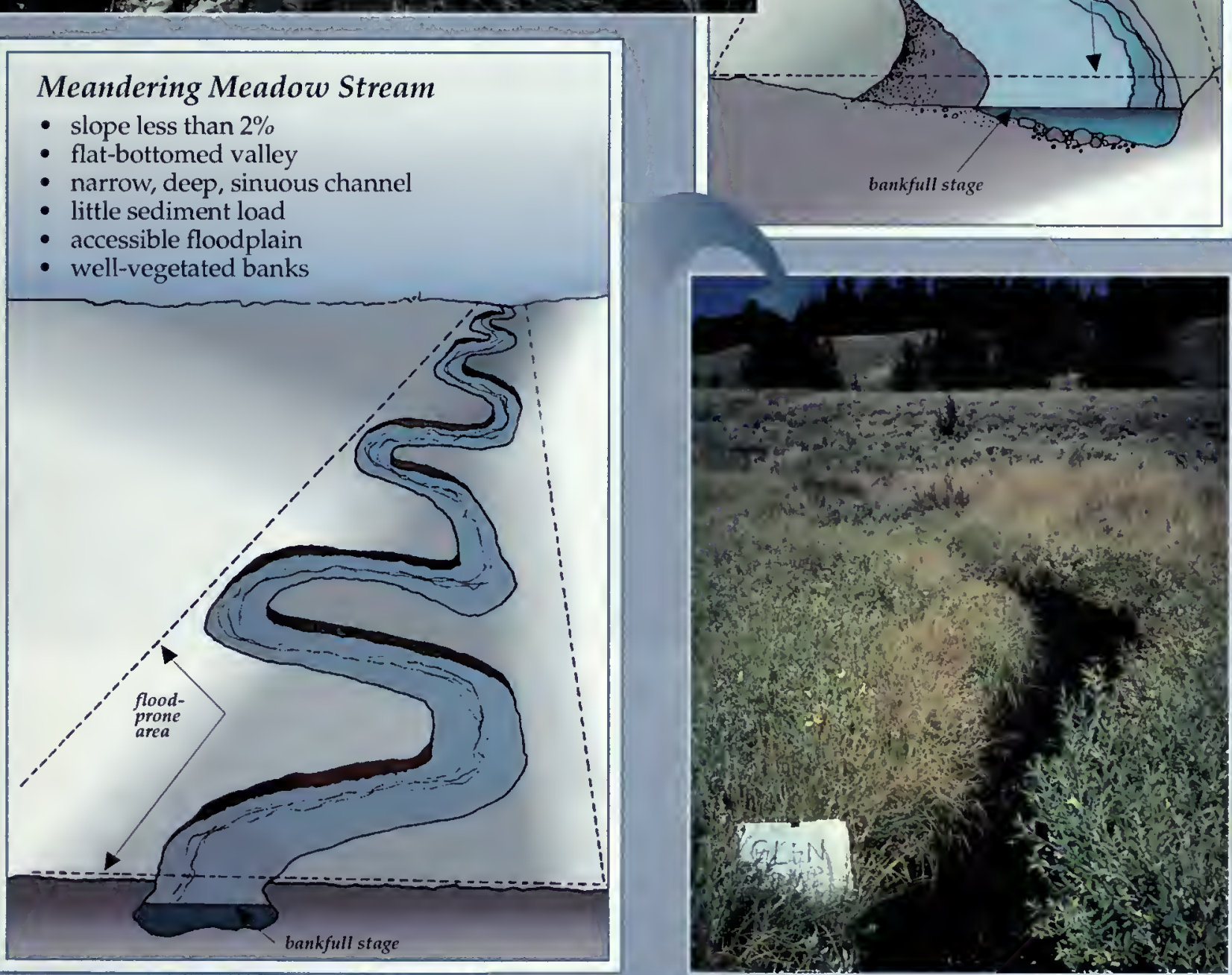


\section{ABOILTSTREALS}

- Unhealthy Stream Types

\section{Common in Montana}

Some Indicators of Unstable Stream Chammels

- channel widening

- unvegetated, eroding stream banks

- channel downcutting

- increased silt/clay on channel bottom

- inability to overflow banks during spring runoff

- increase or decrease in water supply

- increase or decrease in sediment supply

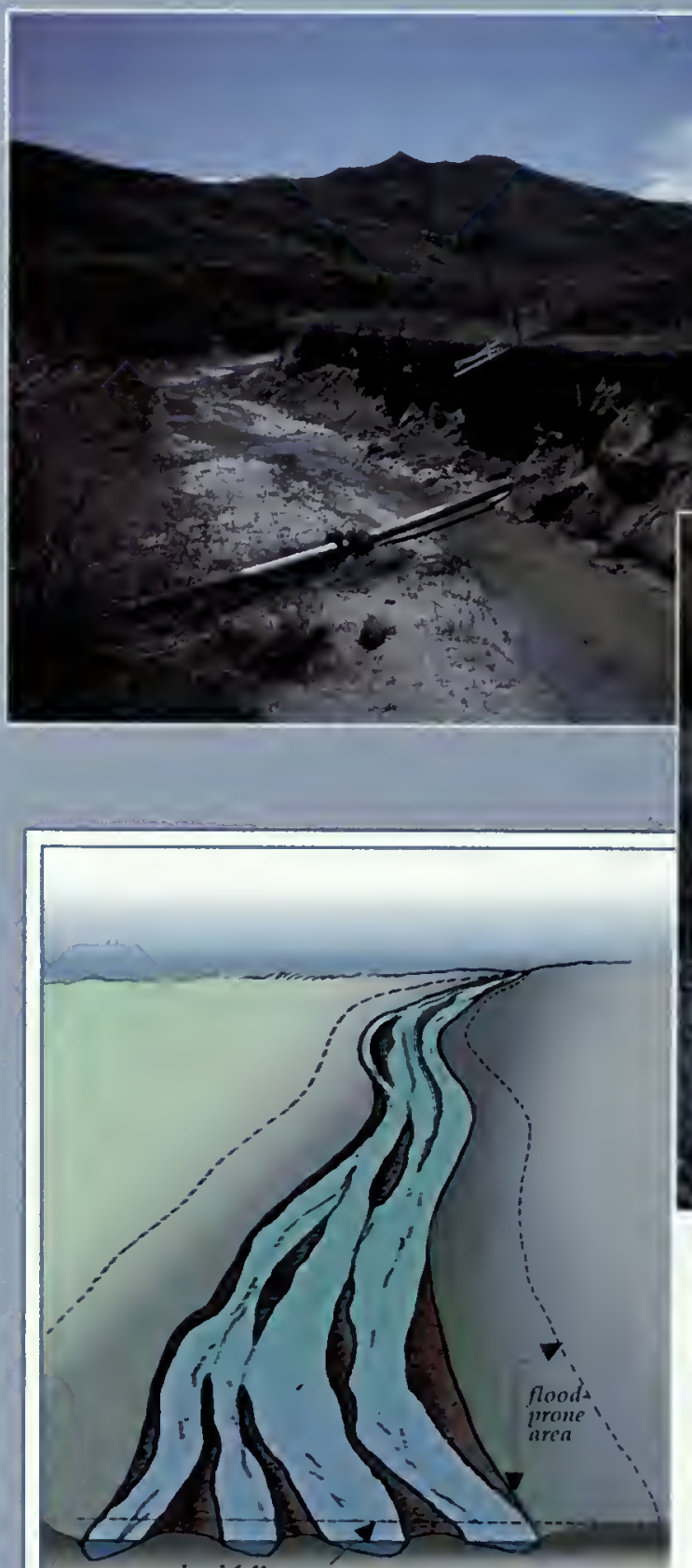

bankfull stage
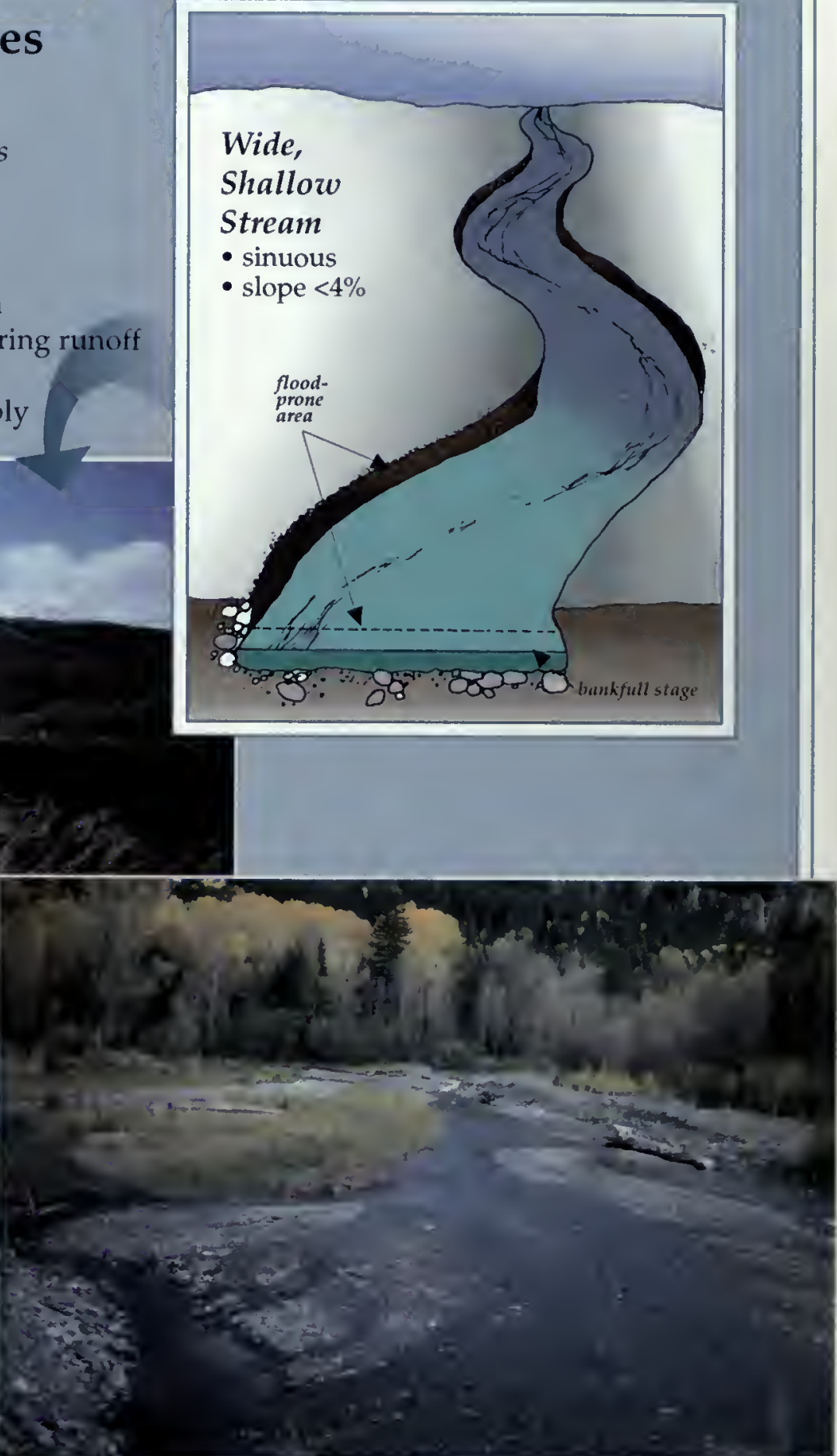

\section{Braided stream}

- slope less than $2 \%$

- multiple shifting channels

- heavy sediment load

- erodes laterally

- wide, shallow

- little aquatic habitat

Some braided streams occur naturally, such as in a glacial headwater environment, but they most often result from human activities that contribute excessive sediment to the stream. 


\section{Unhealthy Stream Types}

Common in Montana
Entrenched/Incised Stream

- slope $2-4 \%$

- gully-shaped channeI

- no access to floodplain

\section{-}

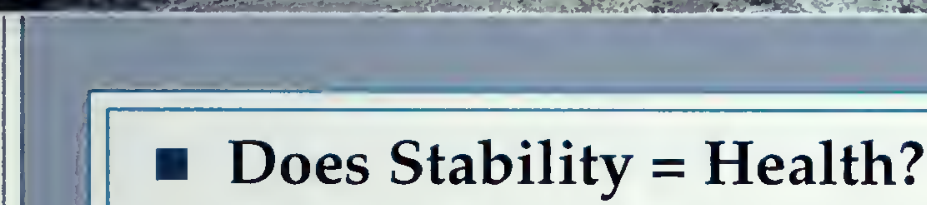

If you're like most stream managers, you'll ask yourself, "Is my stream stable?" Instead, ask yourself the more relevant question: "Is my stream healthy?" Many healthy streams seem unstable as they react over time to normal erosion and other natural disturbances. A healthy stream is moving both water and sediment in a state of natural balance; in doing so, it provides a rich diversity of plant and animal life.

As you think about your stream's health, ask yourself these questions:

1. Is my stream moving water and sediment in balance?

2. Is my stream accessing the floodplain?

3. Are the banks protected by healthy riparian vegetation with dense, bank-binding roots?

4. Is my stream's sinuosity, gradient, or channel shape changing?

5. What is happening in the watershed and how is that affecting my stream?

6. Is my stream in balance with the surrounding environment? 


\section{ABOUT RESTORATION}

Watershed Planning

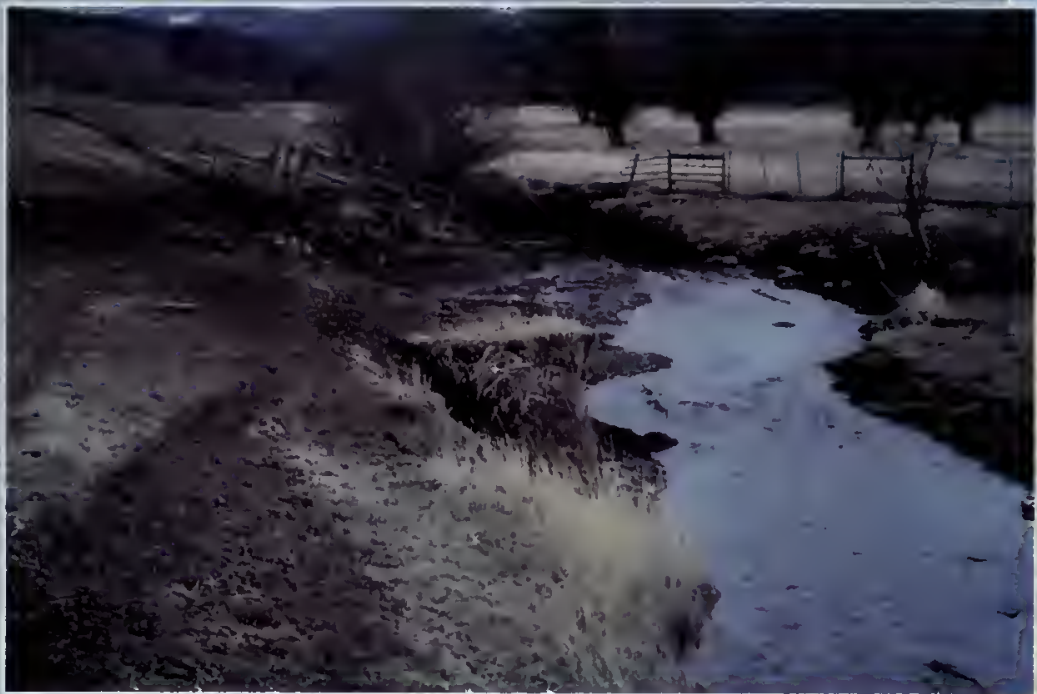

Many of the healthy characteristics of this impacted stream lave been lost...

Watershed planning begins when citizens of a river basin evaluate the condition of their land and water resources. They then develop a plan to restore or keep the resources in top-notch condition while meeting most social, economic, and ecological needs in the basin.

\section{Steps in watershed planning:}

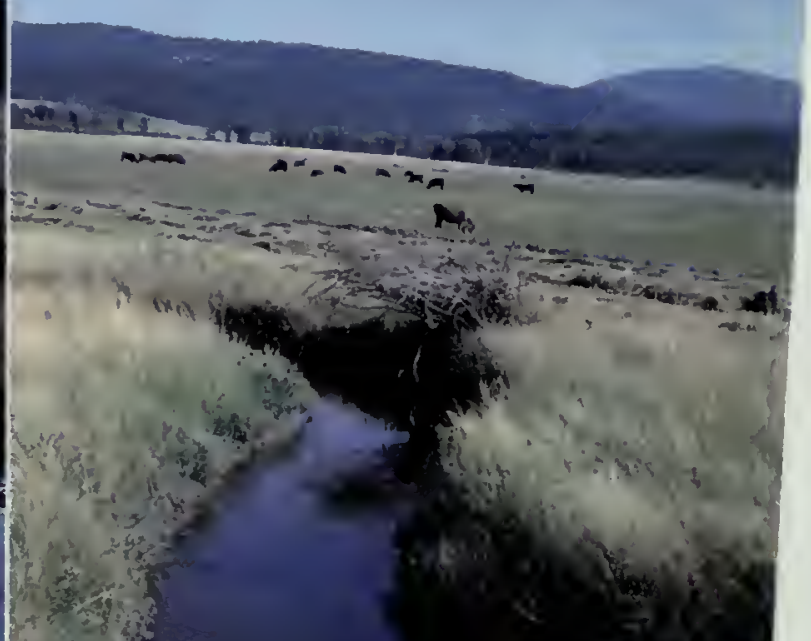

- Form a watershed planning committee that includes a variety of interests and occupations in your basin.

- Hold a public meeting to identify the resource concerns in the basin.

- Form a technical advisory team composed of agencies and organizations that can help you gather information and find solutions.

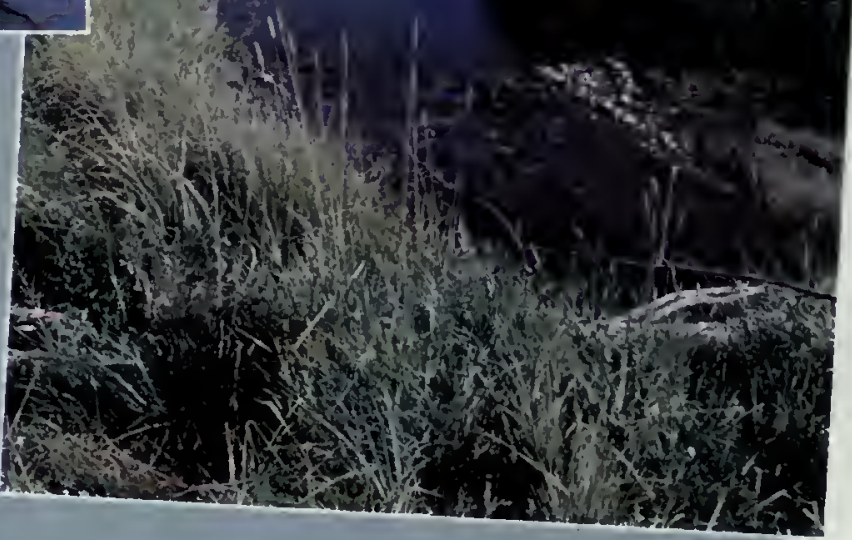

- Conduct an inventory to determine the total stream miles and condition of critical reaches in the watershed.

- Prepare a plan, reviewing the range of alternatives, setting priorities, evaluating cost efficiency and project effectiveness.

- Present the plan to the public to review and adopt.

- Implement the plan using financial and technical assistance available from a variety of sources.

- Review the plan and progress annually.

Stream restoration is part of watershed planning. If something is "broken" or out of balance on a smaller stream in the watershed, it may be fixed by a simple management change, or it may require a realigning of channel sections. Think of it like an automobile when something goes awry-the problem could be a broken belt or a blown engine. So before beginning a restoration project, be sure to identify the cause of the problem and address that first. 


\section{Eight Steps To Restore A Stream}

\section{Get to Know Your Stream}

- Your first step is to familiarize yourself with your stream and its combination of characteristics. Take a walk along, or maybe even in, your stream.

\section{Assess Your Stream \& Streamside Area}

- Identify healthy stream reaches.

- Identify problem areas.

- If necessary, seek assistance from a resource professional.

- Use a stream channel and riparian area monitoring form available from local resource agencies.

\section{Quantify Problems: For example, ask}

- How many feet of stream bank are bare of vegetation and eroding?

- How many feet of stream bank contain noxious weeds or species with poor root structure?

- How healthy is the fish habitat? Are pools and riffles adequate for fish reproduction, rearing, and overwintering?

\section{Prioritize Problems to Address}

- Read Section 3 about common stream problems and their solutions.

- Discuss the stream problems with a stream management specialist.

- Determine which problems can feasibly be corrected by your actions.

- Which problems need the help of your neighbors and community?
To ensure successful restoration, you need to thoroughly plan and carefully implement the restoration. The steps on this page will help you achieve your goals, as will the agencies listed on the next page.

\section{Establish Your Objectives}

- Objectives should be realistic. If you include measurable standards and a workable time frame, you can better gauge your success. For example, you can aim to increase native streambank vegetation by 50 percent in five years.

\section{Develop a Work Plan}

- Evaluate a range of alternatives.

- Compare the costs for different management practices and restoration alternatives.

Implement Your Work Plan

- Obtain all necessary permits.

- Adopt new management practices.

- Improve stream channel stability by actions such as:

-installing tree revetments

-planting streamside vegetation

- Seek qualified contractors to assist you.

\section{Monitor the Restoration}

- Annually evaluate whether you are meeting your restoration objectives. Assess the need for modification and maintenance. Share your observations with stream management professionals so that we all learn how to manage and restore streams successfully. 


\section{The Permits You'll Need}

If you are planning a management activity in or around a stream, you will probably need a permit from a local, state, or federal agency. Use this diagram to determine where your project will take place-streambed, stream banks, wetlands, or floodplain-and what permits you need for activities in that part of the stream. Contact the appropriate government agency for information about acquiring necessary permits. Before issuing a permit, the agency checks to make sure that your plans are technically feasible, have limited or mitigated impacts, and do not affect your upstream or downstream neighbors.
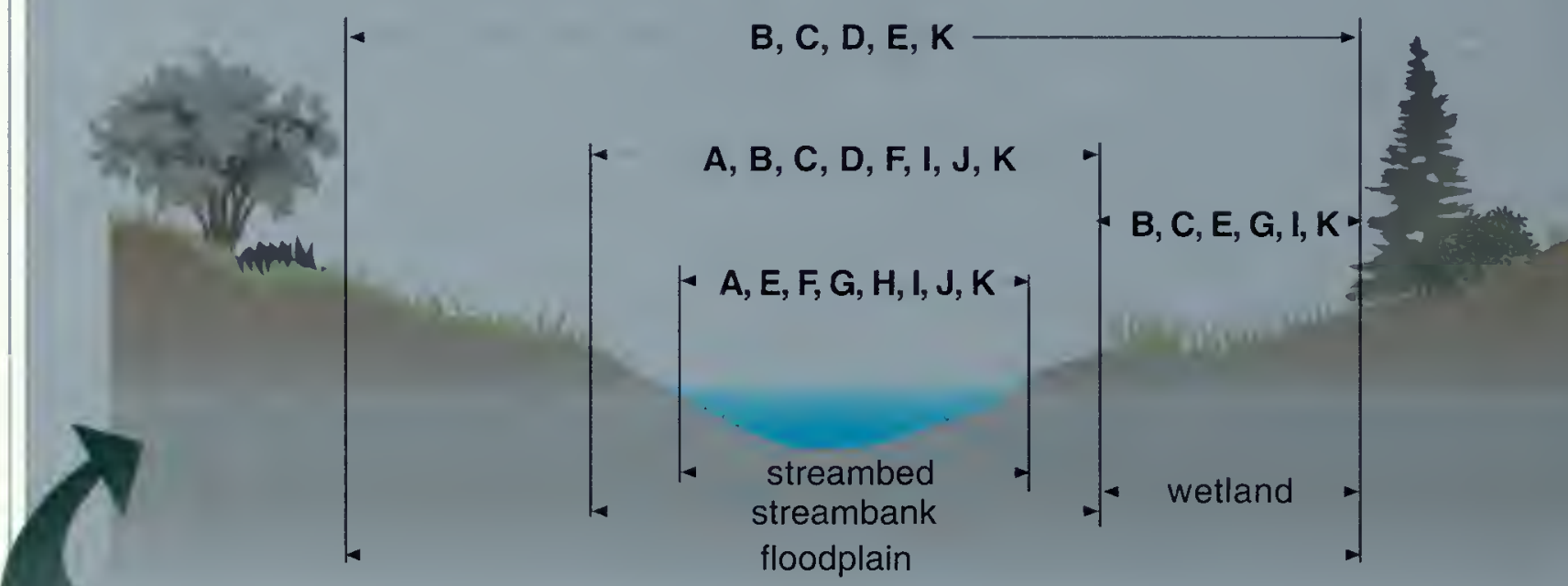

Using this diagram, deternine where your activity will occur. The letters refer to the permits listed below.

\section{Permit}

\section{Government Agency}

Phone

A Montana Stream Protection Act (124)

Montana Fish, Wildlife \& Parks 406-444-2449

B Storm Water Discharge General Permits

Dept. of Environmental Quality 406-444-2406

C Streamside Management Zone Law Dept. of Natural Resources \& Conservation .....406-542-4300

D Montana Floodplain and Floodway Dept. of Natural Resources \& Conservation $406-444-6610$ Management Act

E Short-term Exemption from Montana's Dept. of Environmental Quality 406-444-2406 Surface Water Quality Standards (3A)

F Montana Natural Streambed and Montana Assn. of Conservation Districts and .... 406-443-5711 Land Preservation Act (310) Dept. of Natural Resources \& Conservation ...... 406-444-6667

G Montana Land-use License or. Dept. of Natural Resources \& Conservation/ .... 406-444-2074 Easement on Navigable Waters Special Uses

H Montana Water Use Act Dept. of Natural Resources \& Conservation ..... 406-444-6610

I Federal Clean Water Act (Section 404) U.S. Army Corps of Engineers . $406-444-6670$

J Federal Rivers and Harbors Act (Section 10) ... U.S. Army Corps of Engineers . 406-444-6670

K Other laws that may apply, Various agencies depending upon your location \& activity

For more details, request "A Guide to Stream Permitting in Montana" from the Montana Association of Conservation Districts, 501 N. Sanders, Helena, MT 59601; 406-443-5711. 


\section{WORKING WITH STREAMS}
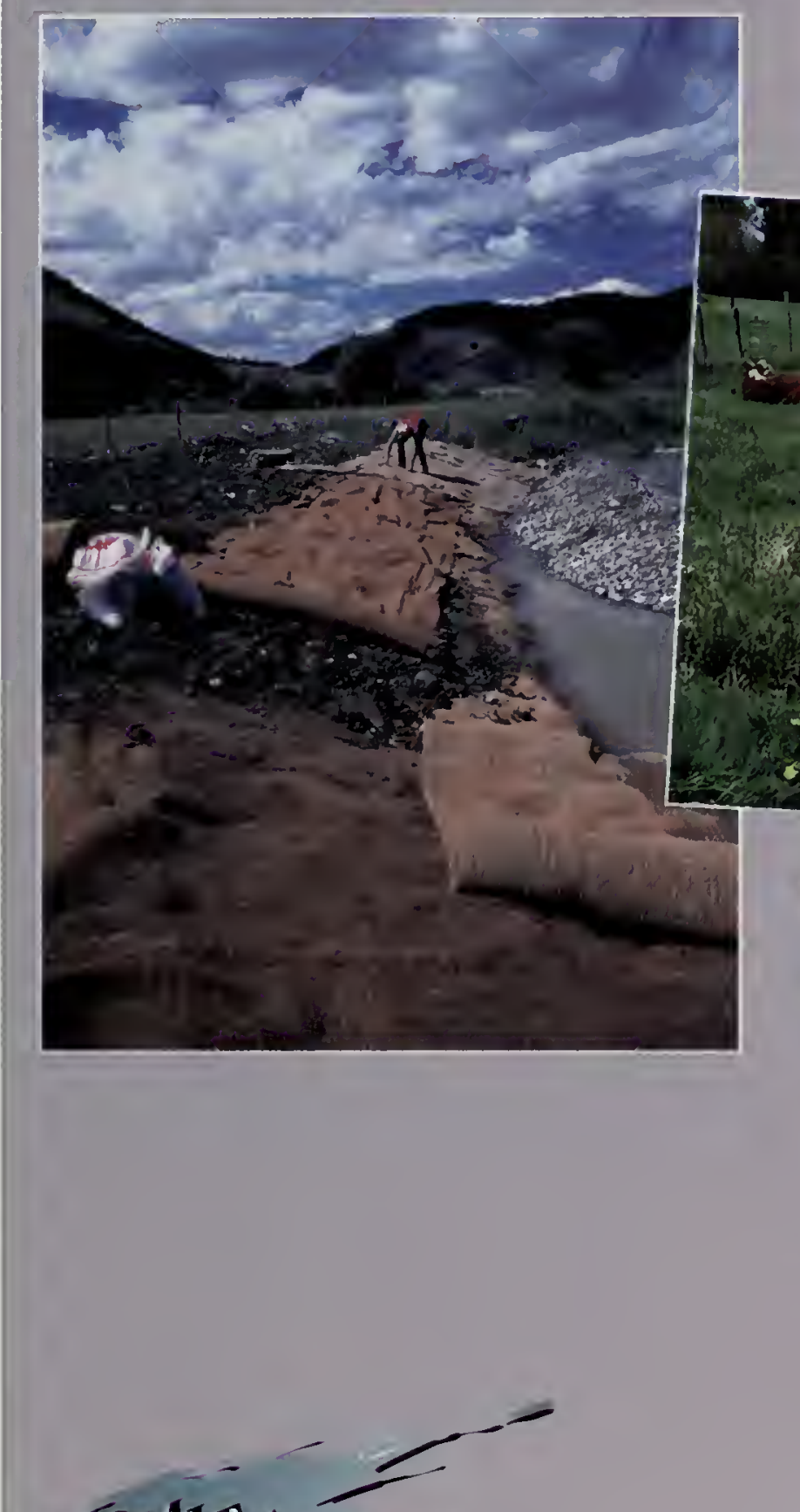

PARMIT ATERT!

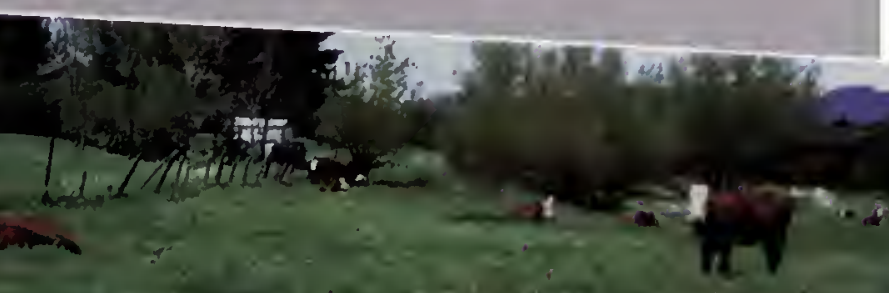




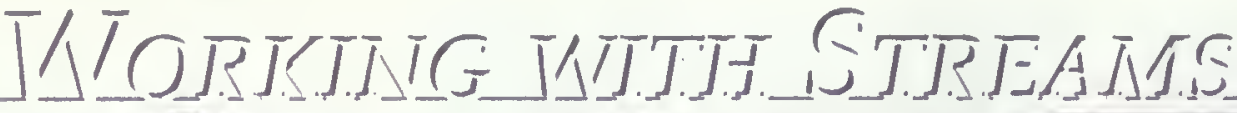

\section{- Riparian \& Streamside Vegetation}

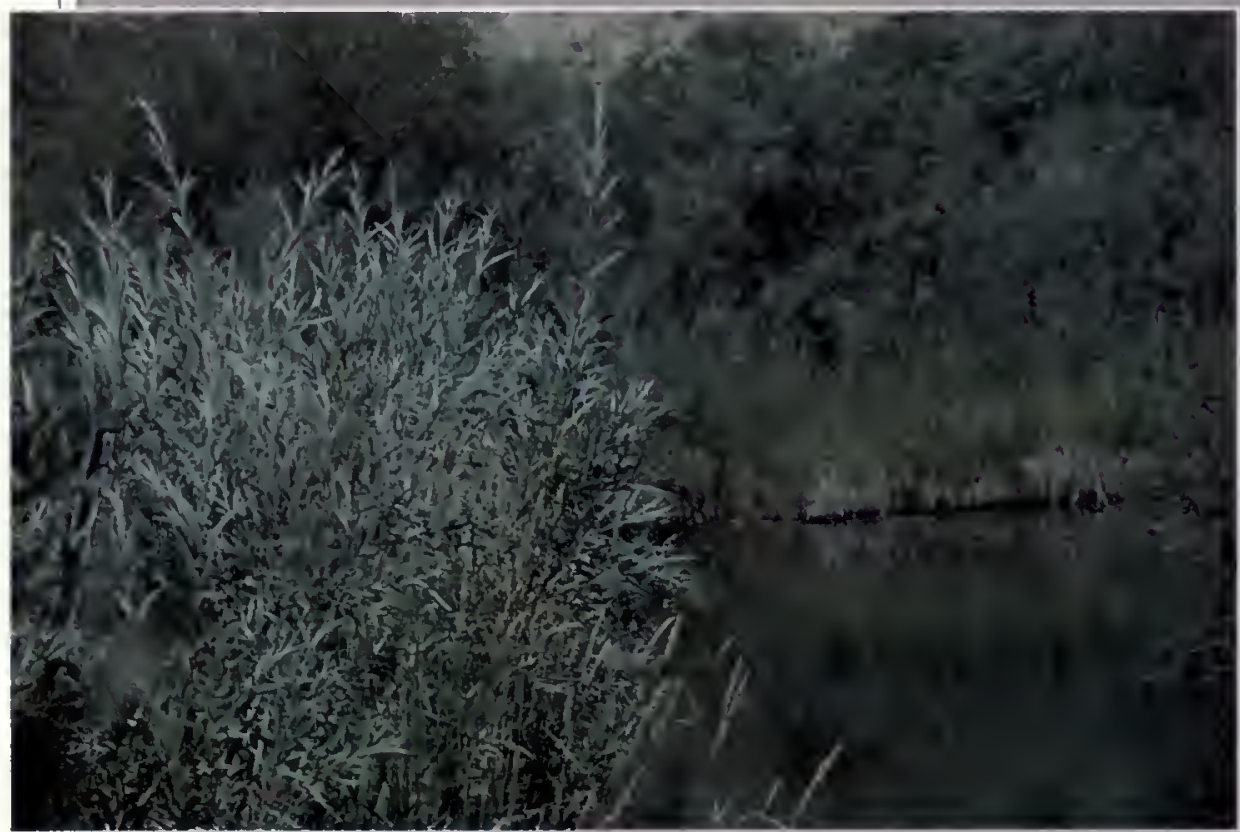

Maintaining healthy vegetation should be your first priority when managing stream and riparian areas. Stream behnviors, such as channel widening and bank erosion, are influenced by the amount and kind of vegetation on stream banks. Healtliy stream banks are covered by deep, densely rooted strenmside vegetntion tlint binds soils. Streambank vegetation also creates friction that slozus strean flows. Removing vegetation, or replacing it with riprap or cement walls, increases stream velocity and sends more erosive stream energy downstrenm.

\section{How We Impact Vegetation}

- Overgrazing by livestock or wildlife

- Spraying herbicides

- Operating heavy equipment in riparian areas

- Building roads

- Clearcutting streamside areas

- Farming to the edge of a stream

- Allowing invasion of non-native species

- Removing riparian vegetation

\section{Effects of Impacting Vegetation}

- Increases bank erosion \& failure

- Widens channels; decreases depth

- Disrupts streamside plant communities

- Increases invasion of non-native plants

- Lowers water table

- Makes stream banks more susceptible to livestock trampling and erosion

- Increases water temperature

- Speeds runoff

- Reduces trapping of sediment and other pollutants

- Reduces livestock forage

- Increases bank damage due to icing

- Decreases valuable real estate

- Decreases fish and wildlife cover

\section{Lessening Our Impact}

- Do not remove riparian vegetation

- Control noxious plants

- Manage grazing intensity, vary season of use, and provide sufficient rest to encourage plant vigor and regrowth

- Ensure sufficient vegetation during spring runoff or peak flow to protect stream banks, dissipate stream energy, and trap sediments

- Control the timing of grazing to prevent damage to stream banks when they are wet and most susceptible to trampling

- Re-establish native and appropriate non-native plant species 


\section{Water Quality}

Sediment is the number one polluter of streams in Montana. Other pollutants include chenuicals, pesticides, herbicides, mutrients, minerals, and salinity. Human-caused changes in temperaturc, such as warming or cooling, are also considered pollution. All of these pollutants limit the way that water can be used by humans and other life.

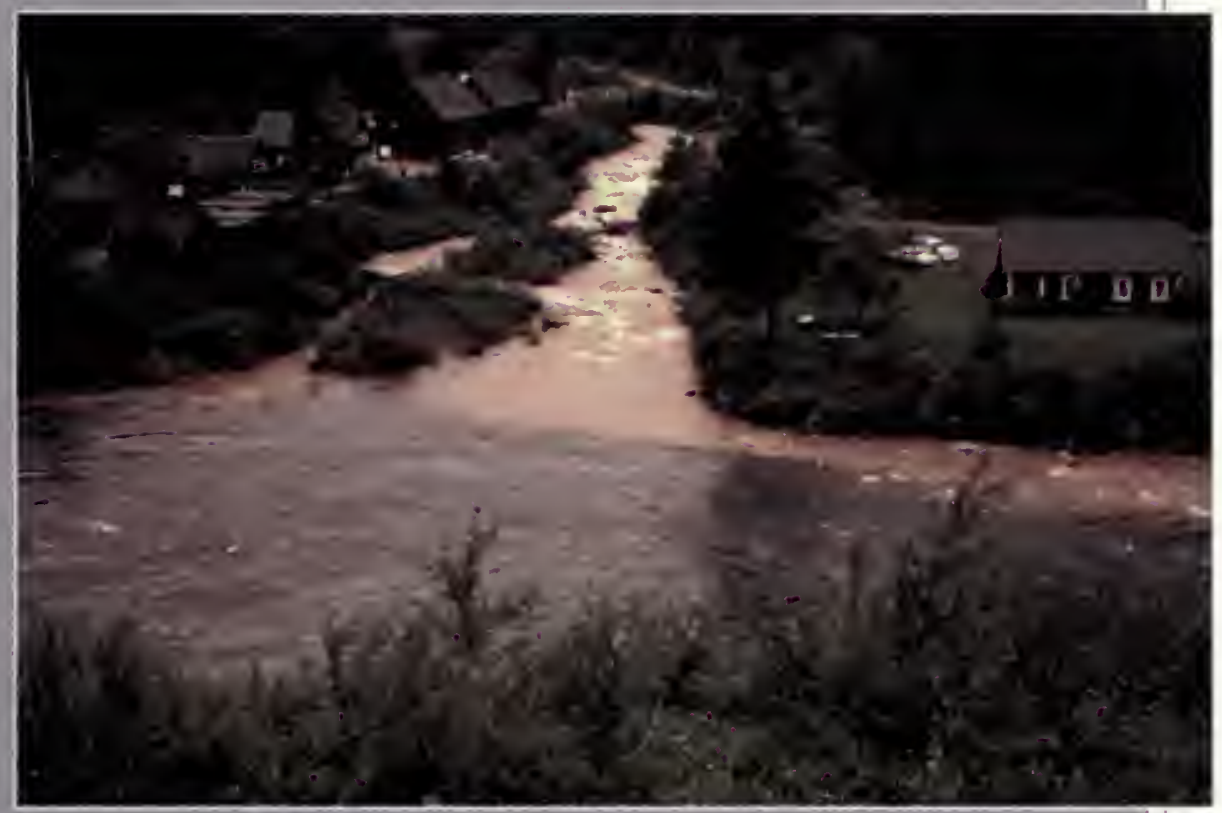

\section{How We Impact Water Quality}

- Point source pollution enters a stream from a known point, such as a discharge pipe, and is usually municipal or industrial in nature. It accounts for approximately 10 percent of water pollution in Montana.

- Non-point source pollution enters streams from dispersed areas, such as windblown sediment and runoff from roads or crop lands. It accounts for 90 percent of stream pollution. Non-point source pollution is usually associated with poorly planned land management activities.

\section{Effects of Our Impact}

- Can eliminate entire aquatic communities and make water unsafe for human use

- Increases temperature, which can biologically suppress stream systems

- Increases costs of water treatment, and reduces usefulness of pumps and ditches

- Affects water quality downstream because effects tend to accumulate throughout watershed

\section{Lessening Our Inipact}

- Protect riparian areas--they filter non-point source pollution such as sediments and nutrients from runoff

- Adopt the Best Management Practices (BMPs) for agriculture, grazing, timber harvesting, and mining to minimize pollutants entering streams and rivers

- Obtain permits before starting any activity that may impact water quality 


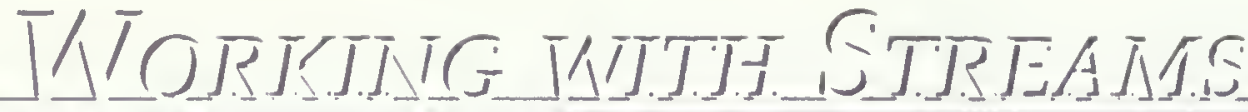

- Floodplains

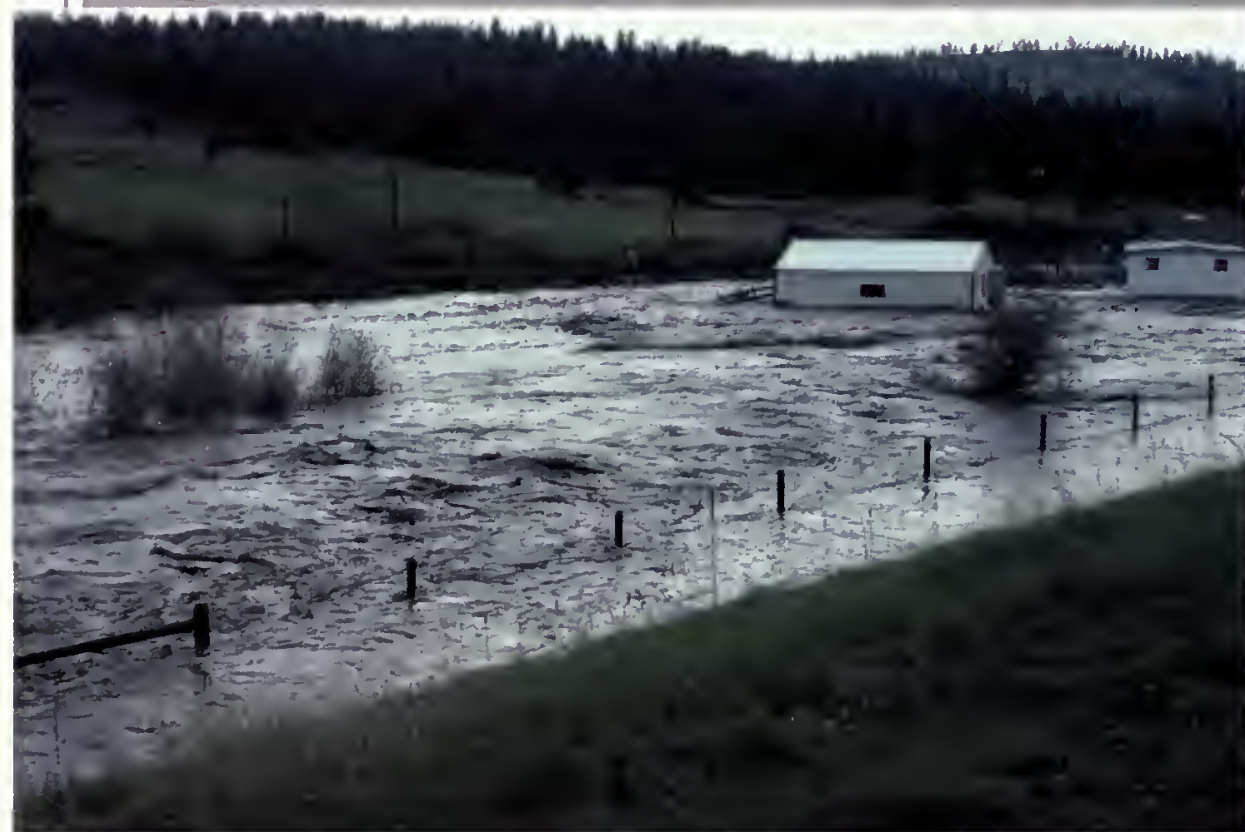

During a flood is not the time to figure out that you built your house in the floodplain, too close to a stream.
Floodplains are critical components of a healthy stream or river system. They provide room for flood waters to spread out and soak in to recharge groundwater and to redice the flood's erosive energy. The fertite soil of floodplains enables abundant vegetation to grow and provides important wildlife habitat. If you armor your stream bank and raise its height to prevent flooding on your land, you are sending more erosive energy downstream to your neighibors.

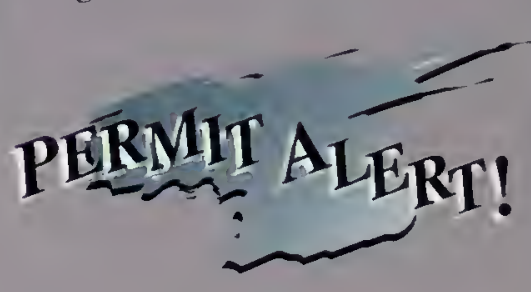

\section{How We Impact Floodplains}

- Poor agricultural and grazing practices

- Residential and commercial construction

- Protecting property by building dikes, levees, and retaining walls; by installing riprap; and by eliminating overflows into side channels

\section{Effects of Our Impact}

- Decreases ability of floodplain to disperse stream energy during flood flows, which:

-Increases energy of flood downstream

-Increases peak flood levels

- Increases bank and bed erosion on neighboring property

- Decreases vegetation cover, which may cause spring runoff to occur earlier and over a shorter period of time, and to produce higher peak flows

- Decreases ability of floodplain to recharge local aquifers, which:

\section{Effects of Our Impact (continued)}

-Decreases riparian vegetation

-Reduces channel flows in drier months

- Reduces aquifer volume

- Increases size and frequency of floods, causing more damage to property and stream channels

- Increases pumping costs

\section{Lessening Our Impact}

- Avoid construction in the floodplain

- Do not restrict floods from flowing into side channels without consulting stream management experts and obtaining a permit

- If construction activities must occur on floodplains, minimize disruption of the soils and vegetation

- Use agricultural methods that minimize impact on floodplain

- Establish greenbelts or stream protection corridors in floodplains 


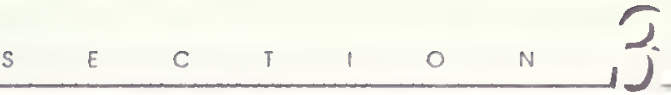

\section{- Channel Constrictions}

A streanl channel's cross section reflects the amount of water and sediment carried by the strenm. If you change the strean's width by cither narrowing or widening it, youl alter its ability to transport water and sediment. Such changes cause other problenis both upstream and downstream.

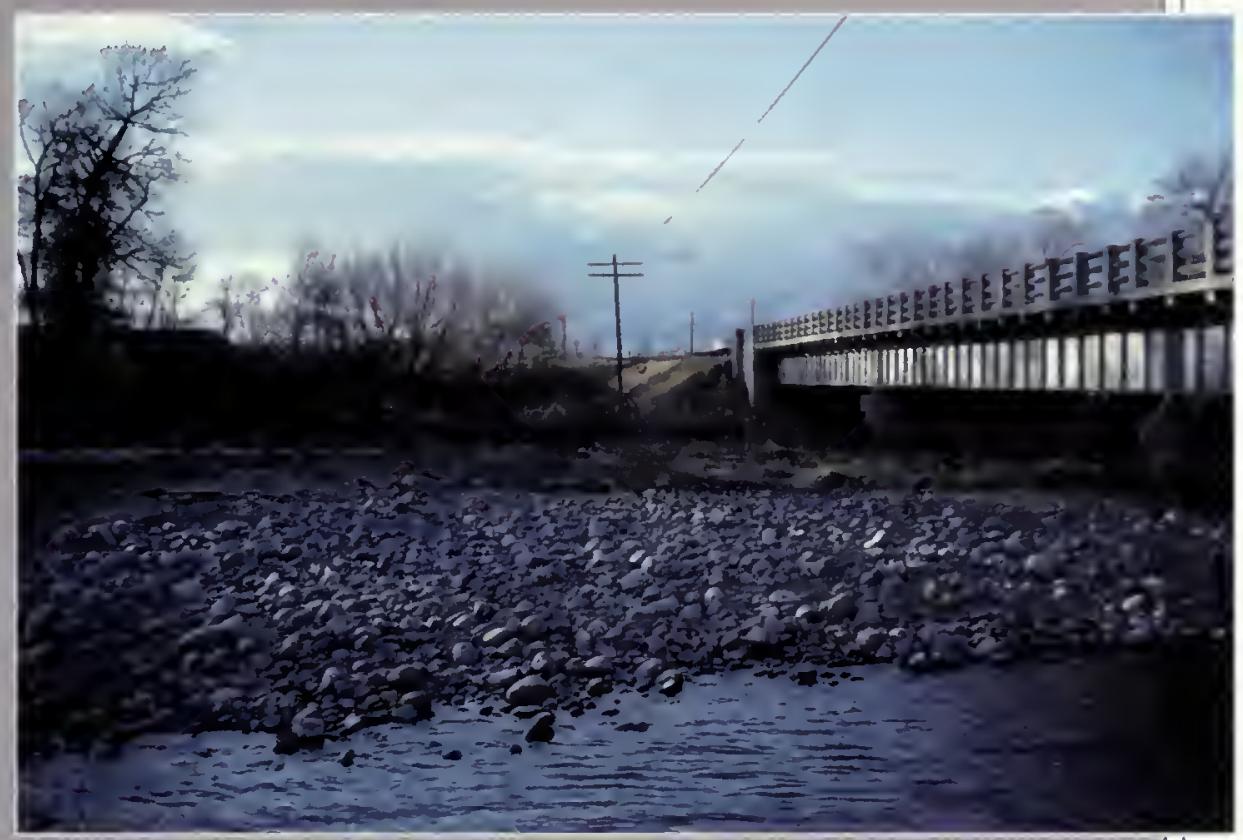

\section{How We Impact Stream Channels}

- Building bridges, berms, levees, roads, and railroads

- Cutting off side channels

- Installing culverts

- Placing debris or riprap along the banks

\section{Effects of Our Impact}

- Can increase the erosive energy at a particular location, which:

- Increases erosion of stream bed and banks -Creates down-cutting (incision) of channel, which leads to lowering of local water tables and loss of riparian vegetation

- Creates low-energy backwater

- Increases filling of sediment

-Increases bank erosion

-Elevates flood flows

\section{Lessening Our Impact}

- Avoid confining channel

- Ensure that stream crossings, such as bridges and culverts, are large enough to pass flood flows

- Replace undersized stream crossings

- Stabilize erosive areas that add sediment to the water

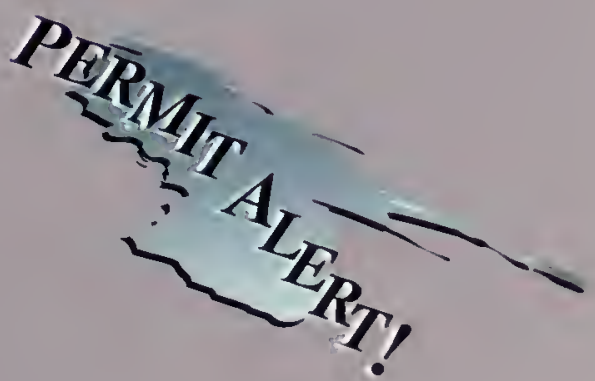




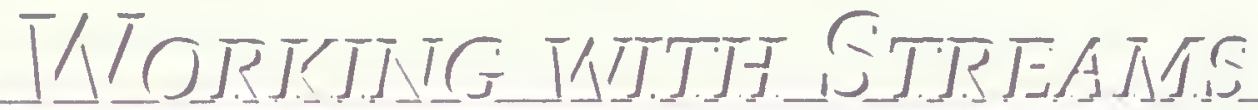

\section{- Channel Widening}

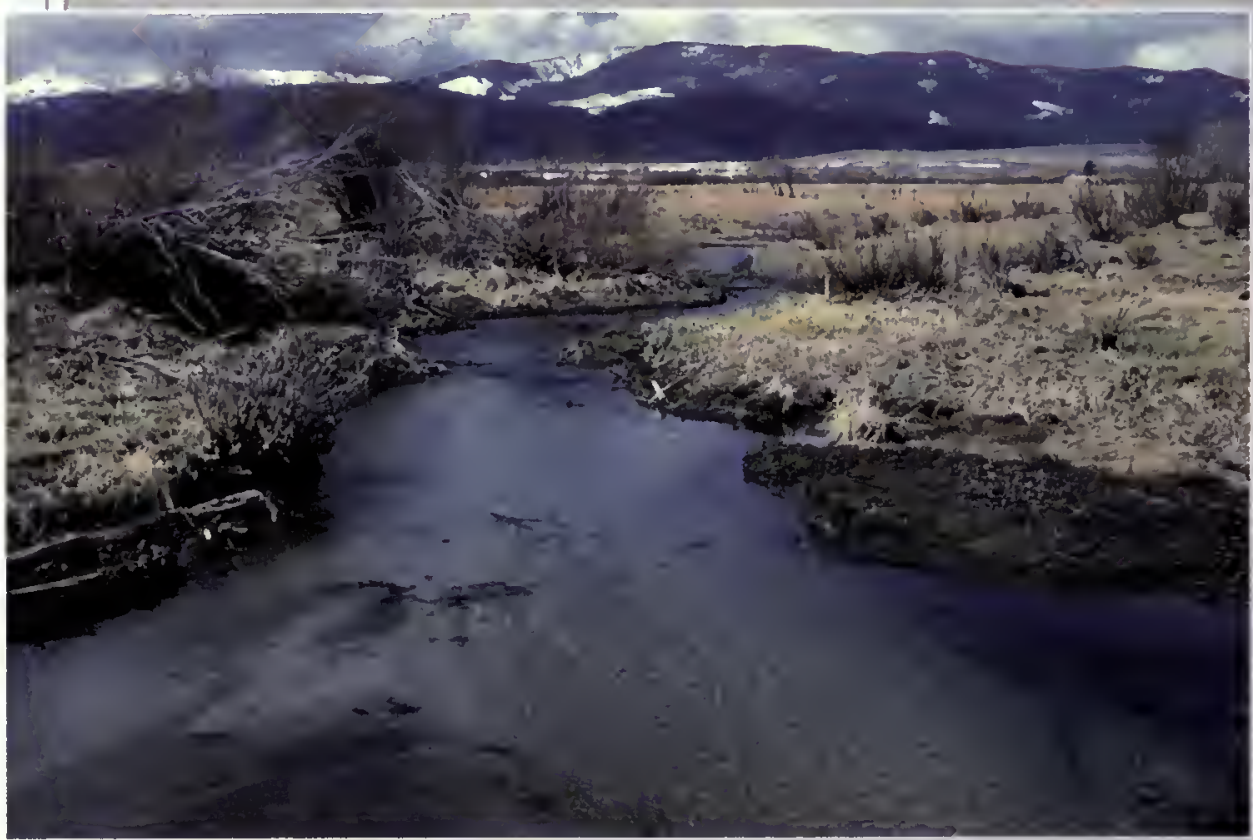

If your stream lacks pools and riffles, and seems unusually shallow, it may have an overly wide chaminel. Channels begin to widen if banks are trampled, vegetation is removed, or the channels become loaded with more sediment than they can carry. The sedinent settles and begins to fill the channel. The same amount of water is now trying to flow through a smaller channel. As a result, the channel begins to widen.

\section{How We Impact Channel Width}

- Overgrazing and trampling by livestock

- Causing any degradation of the upstream banks, floodplains, or riparian areas

- Increasing amount of sediment either upstream or in immediate area

- Increasing flood flows by decreasing vegetation upstream

- Transferring water from one stream to another within the same watershed (interbasin water transfer)

\section{Effects of Our Impact}

- Increases bank erosion

- Increases need to treat drinking water

- Increases maintenance of irrigation pumps, diversions, and ditches

- Increases sediment loads, which encourages erosion and widening further downstream

- Decreases vegetation

- Decreases fish habitat by filling in pools and spawning areas and by warming water in summer and icing water in winter

- Eliminates riparian habitat

\section{Lessening Our Impact}

- Protect riparian vegetation

- Stabilize upstream erosion by replanting vegetation

- Manage riparian areas to prevent erosion

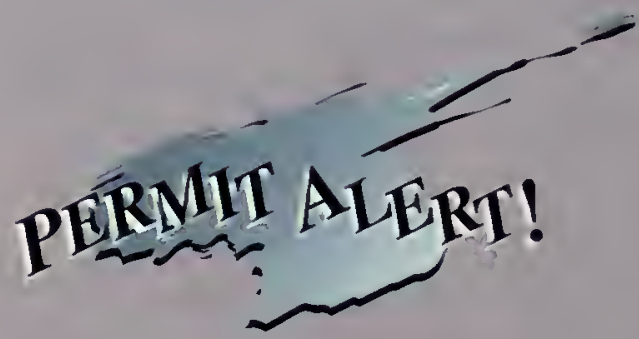


S C T $1,0 N N$

- Channel Entrenchment

Entrenched channels are decp with high banks. Entrenched channels are most frequently found in highly erodible terrain. Changes in a channel's hydrology, sediment supply, or crosive energy can causc entrenchment, zolich is also called downcutting.

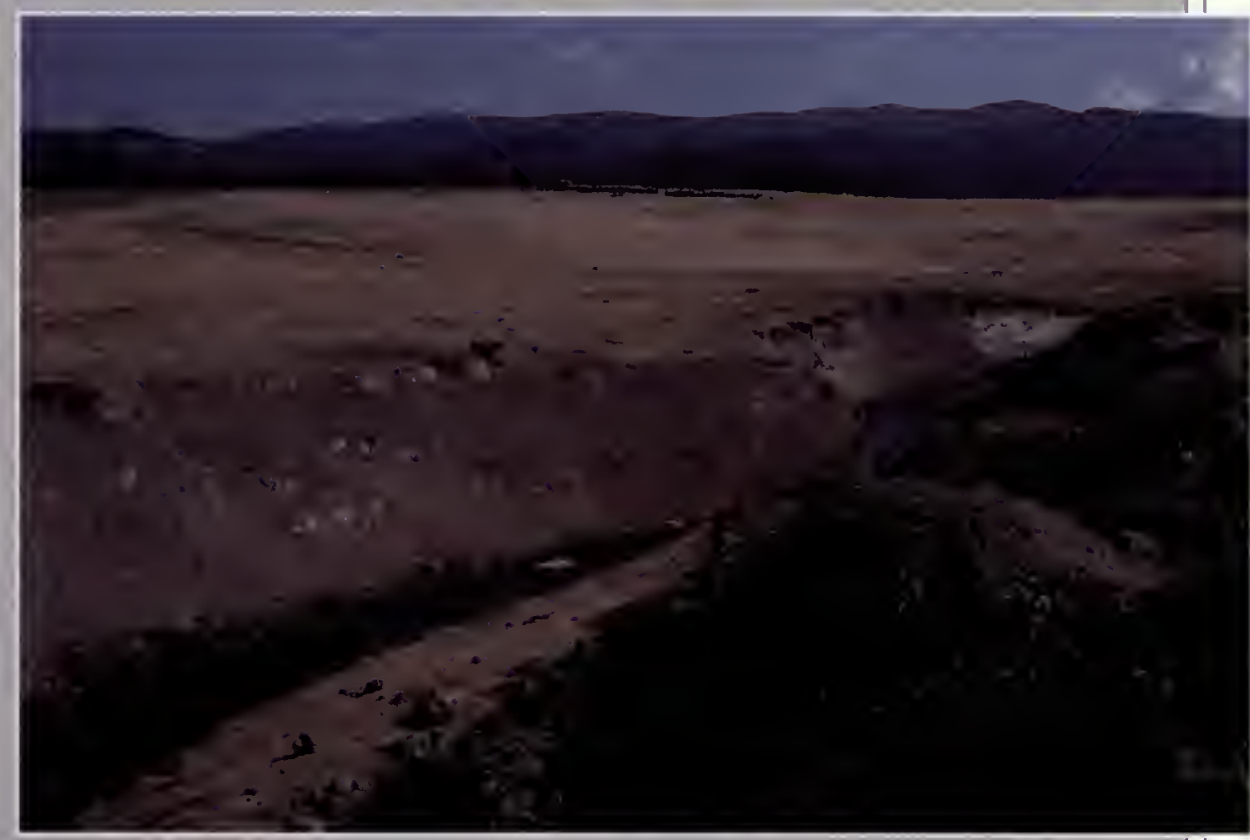

\section{What Causes Entrenchment?}

- Straightening or shortening a channel

- Decreasing sediment supply, such as by trapping sediments in upstream reservoirs

- Increasing channel's water supply

\section{Effects of Entrenchment}

- Lowers level of local water table to new stream elevation, which:

- Changes streamside plants and affects fish habitat and stream flow

-Impacts irrigation diversion and groundwater wells

- Eliminates access to the floodplain, which increases stream energy and bank erosion

- Reduces aesthetic values and recreational uses

- Reduces property value

- May increase water supply to a channel

\section{Lessening the Impact}

- Prevent downcutting by protecting channel and banks from erosion, and by maintaining healthy vegetation along stream banks

- As soon as you notice downcutting, consult a stream management specialist for help

- Conduct a stream inventory or tour the upper watershed to identify potential problems

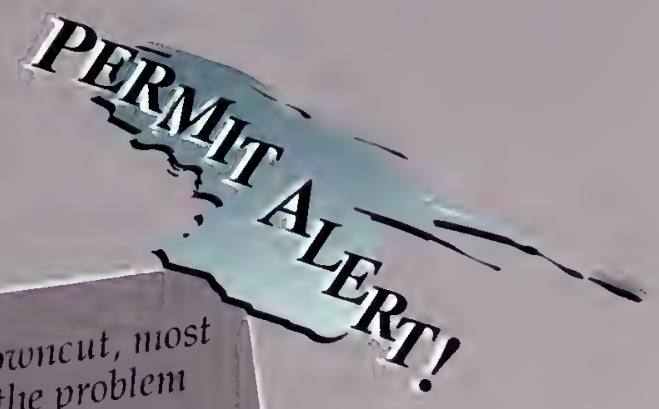

Once a channel is deeply downe problent streant manngers consider the prective irreversible becanse fero ce solutions are available. 


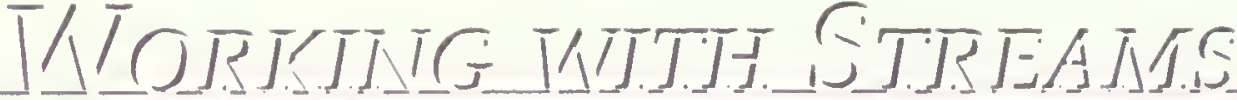

\section{- Channel Straightening}

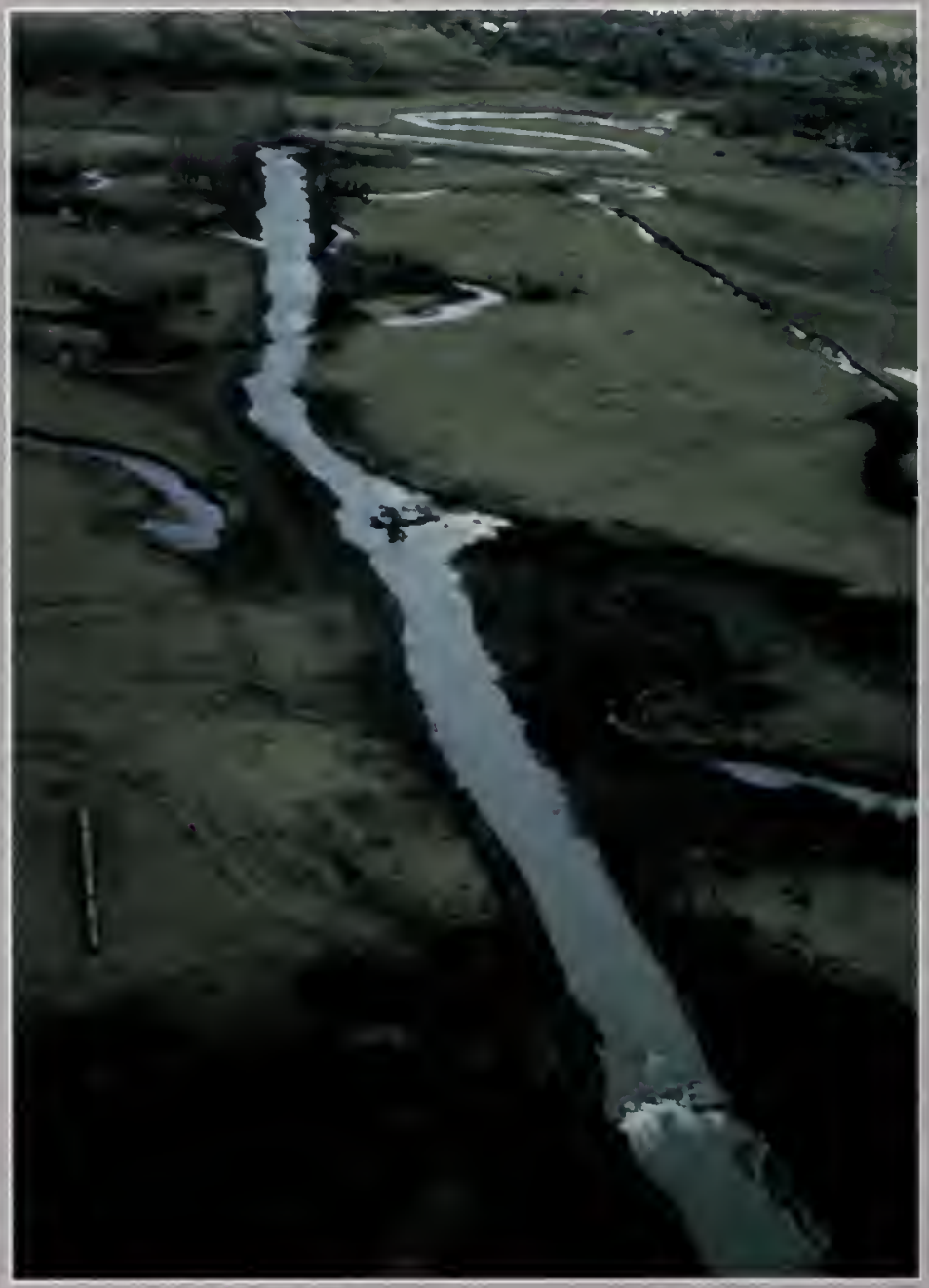

\section{Why Streams are Straightened}

- To reduce the number of highway and railroad crossings

- To develop land more easily along streams

- To control overbank flows

- To protect property by eliminating channel migration

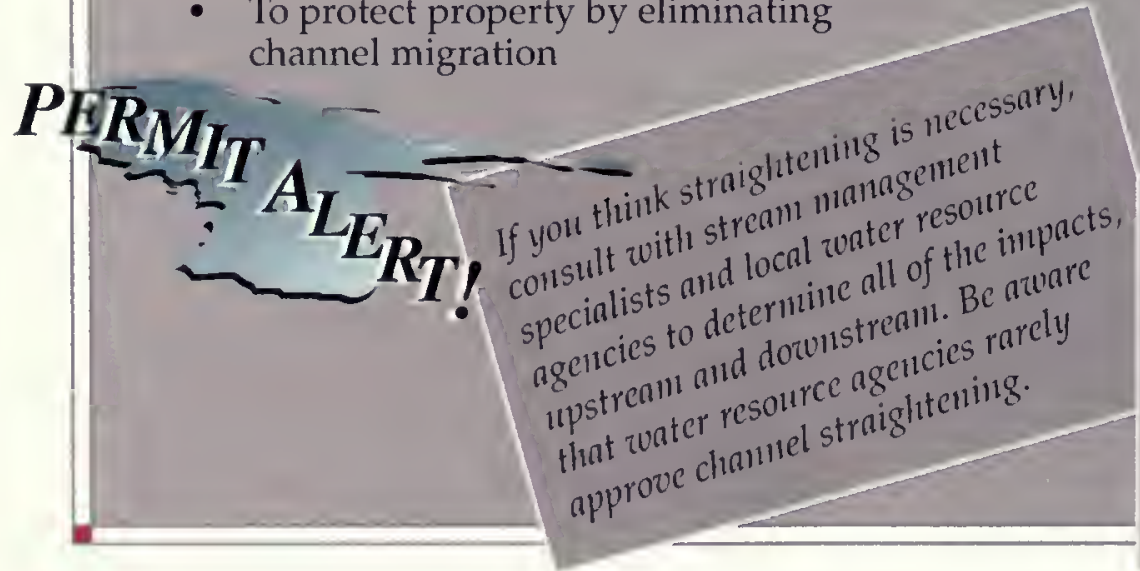

Streams that flow through steep, narrowe valleys run relatively fast and straight. But once a stream moves into less steep and less confining land forms, it slows and begins to curve and meander. When the natural sinuosity of a stream is altered, the stream becomes steeper and its flow increases in energy. The stream reacts to these changes by making adjustments.

\section{Effects of Our Impact}

- Eliminates meanders and shortens stream length, which increases slope and reduces natural energy dissipation

- Increases velocity of water, which increases erosion downstream

- Increases flood intensity - Speeds movement of peak flows -Eliminates storage capacity of stream

- Decreases channel stability and increases channel migration as the channel attempts to come to a new equilibrium; this also increases problems upstream and downstream

\section{Lessening Our Impact}

Stream managers rarely recommend straightening chamels. Instead, they suggest these alternatives:

- Plan roads and other developments away from streamside areas

- Control upstream sediment sources to reduce downstream instability

- Stabilize channel banks

If your stream is already straightened, consult a stream management specialist about restoring straightened sections to their original channel shape and pattern. 
$S \quad E \quad C \quad T \quad 1 \quad 00 N$

\section{- Streambed Disturbance}

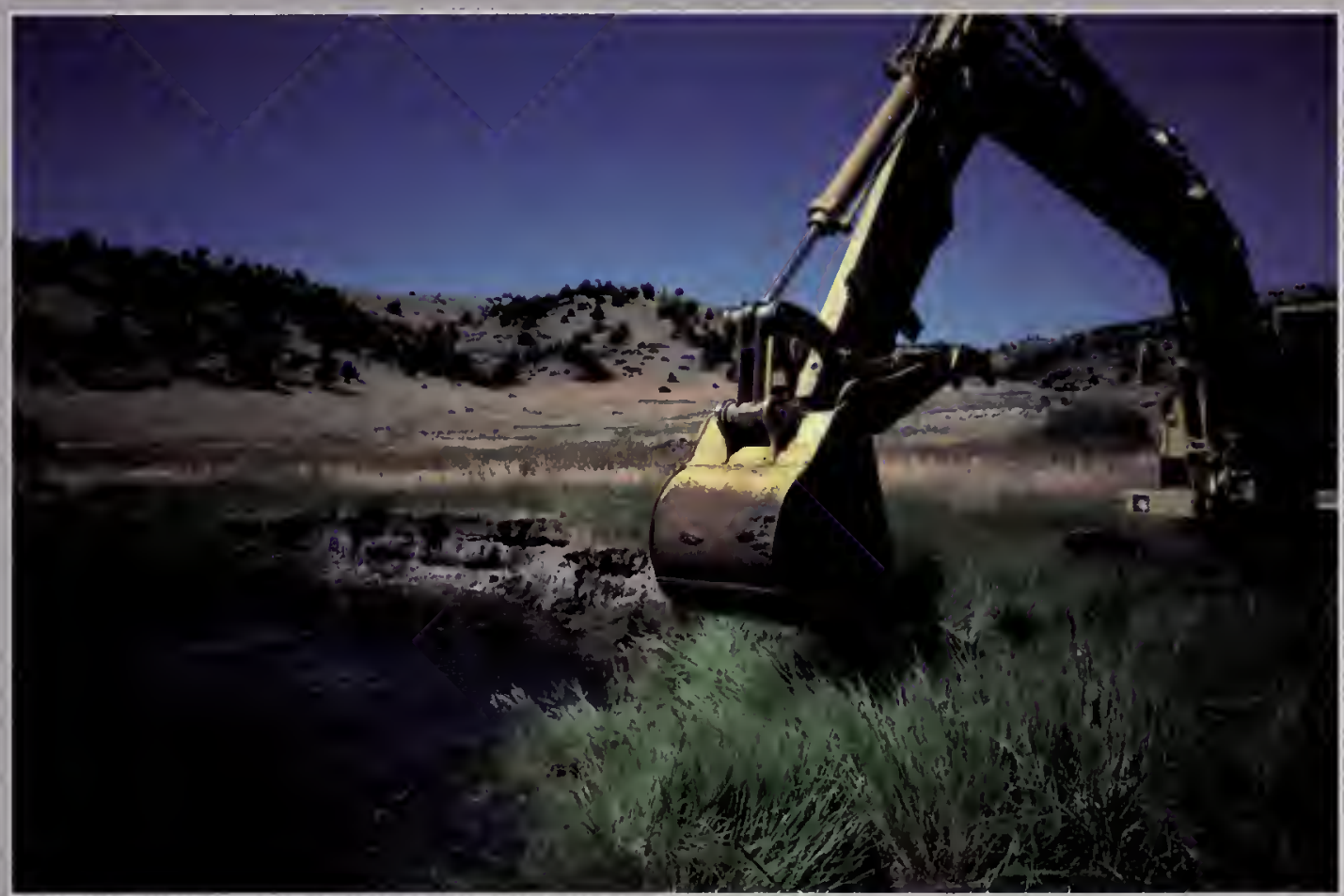

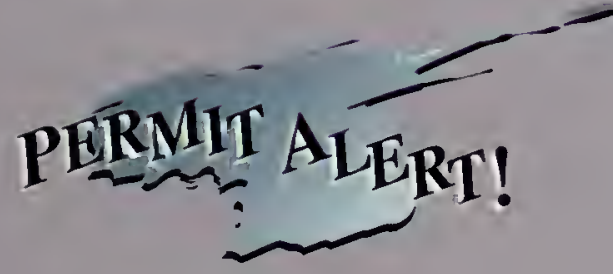

In Montana's dry climate, streams usually lose water as gravity pulls water into the ground. The material making up the streambed controls the rate that water is lost from the strenm. Fine sediments often seal a streambed and slow the loss of stream water. If henoy equipment or other activities disturb the fine sediments, water can seep into the aquifer at a much higher rate. This can cause an entire reacli of the stream to go underground for a while.

\section{How We Impact the Streambed Seal}

- Operating heavy equipment in the stream channel

- Removing or disturbing channel bed materials

Placer mining, for example, impacts strenmbed seals in both of these ways

\section{Effects of Our Impact}

- Increases water seepage into aquifer

- Reduces water available for in-stream use and downstream users

- Increases water temperature in the summer

\section{Lessening Our Impact}

- Operate heavy equipment in the stream channel only when absolutely necessary

- Use irrigation diversion alternatives that do not require operating heavy equipment in stream channels 


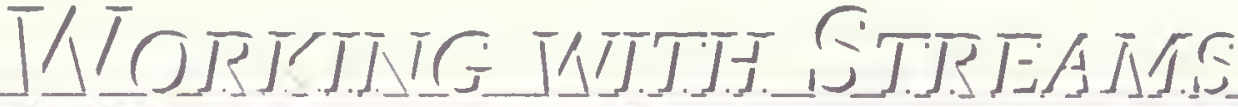

\section{- Dewatering}

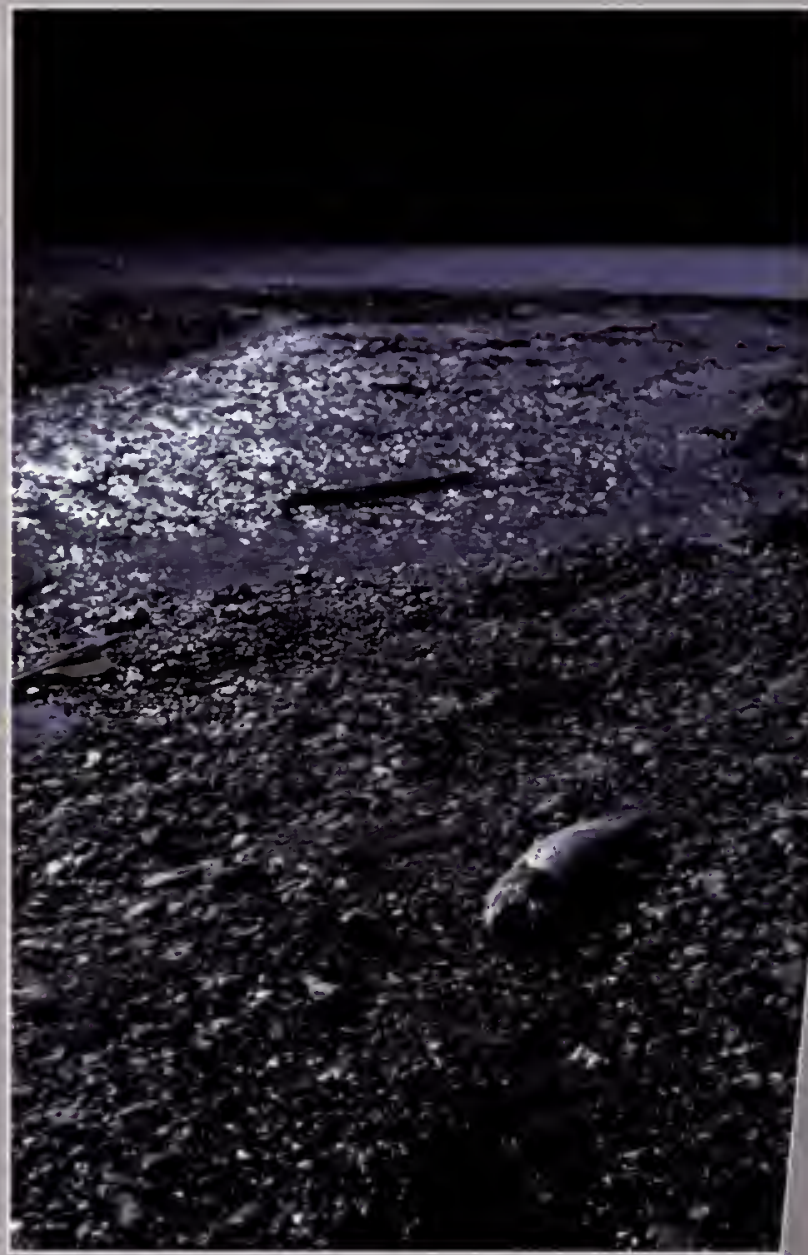

In many watersheds within Montana, more water rights exist than water. Because of this over-appropriation of water, streams are deanatered on a regular basis by people exercising their water rights. Dewatering occurs every year but is especially intense during droughts.

\section{Lessening Our Impact}

- If possible, provide more water for instream flows

- Use irrigation water efficiently

- Use only legally appropriated water shares

- Try to manage reservoirs for water flows and fisheries

- Consider leasing water rights for instream use

\section{How We Impact Water Levels}

- Over-appropriating water

- Building dams

- Storing water in reservoirs

- Transferring water from one basin to another

\section{Effects of Our Impact}

- Disrupts natural life cycles of animals such as trout that depend on seasonal flows

- Decreases aquatic habitat by decreasing amount of water and vegetation

- Changes streamside vegetation from native riparian species to less-productive dryland species

- Increases water temperature

- Can alter natural cycle of high spring and low

Dain construction for water storage can improve water supplies, but it tends to an natural hydrologic cycle of it tends to alter the winter flows. Many specie of high spring and low trout, are adapted to this of wildlife, such as time their reproduction to coincide cycle and seasonal flozus. Reserooir to coincide with can result in streans bein refilling or storage greatly reduced in volung dewatered or flow's winter flows

- Can cause ice buildups if winter water flow is low; this causes ice jams that can scour stream banks, fish habitat, and adjacent properties

Changing water appropriations and legalizing in-stream water rights will require new legislation. You can improve water new legislation. You can improve ing irrigation
conservation, though, by changing
practices. To learn more about reducing your consumption of irrigation water, consult local state agencies, including the Montana Department of Natural Resources and Conservation, and the U.S. Natural Resource Conservation Service. 


\section{- Methods \& Costs of Streambank Alteration \& Stabilization}

The cost of bank stabilization measures varies. You can use this chart to compare costs, advantages, and disadvantages of different strategies.

\begin{tabular}{|c|c|c|c|}
\hline Stabilization Measure & AdVANTAGES & DisadVANTAGES & Costs * \\
\hline \multicolumn{4}{|l|}{ Management Changes } \\
\hline $\begin{array}{l}\text { Implement grazing and agricultural } \\
\text { practices that allow vegetation to } \\
\text { recover. }\end{array}$ & $\begin{array}{l}\text { Easiest to implement: natural } \\
\text { recovery; diverse } \\
\text { opportunities. }\end{array}$ & Results take time. & $\begin{array}{l}\text { Low to moderate. } \\
\text { Long-term increase } \\
\text { in productivity may } \\
\text { offset initial costs. }\end{array}$ \\
\hline \multicolumn{4}{|l|}{ Revegetation } \\
\hline $\begin{array}{l}\text { Plant native shrubs: reintroduce } \\
\text { native grasses and sedges. }\end{array}$ & $\begin{array}{l}\text { Can be accomplished with } \\
\text { hand labor; recovery of } \\
\text { streamside habitat. }\end{array}$ & $\begin{array}{l}\text { Labor/cost intensive; results } \\
\text { take time; need riparian } \\
\text { expertise; may need short- } \\
\text { term change in land use. }\end{array}$ & $\begin{array}{l}\text { Low to moderate, } \\
\$ .50-\$ 10 \text { foot. Costs } \\
\text { reflect labor, } \\
\text { availability and cost } \\
\text { of plants. }\end{array}$ \\
\hline \multicolumn{4}{|l|}{ Recontouring } \\
\hline $\begin{array}{l}\text { Increase streambank slope, then } \\
\text { cover with erosion blankets and } \\
\text { replant native vegetation. }\end{array}$ & $\begin{array}{l}\text { High chance of success; } \\
\text { recovery of riparian habitat. }\end{array}$ & $\begin{array}{l}\text { Requires design and } \\
\text { installation expertise, heavy } \\
\text { equipment, and labor. }\end{array}$ & $\begin{array}{l}\text { Moderate to high, } \\
\$ 10-\$ 100 / \text { foot, } \\
\text { depending on bank } \\
\text { height and intensity. }\end{array}$ \\
\hline \multicolumn{4}{|l|}{ Riprap } \\
\hline $\begin{array}{l}\text { Rocks and boulders cover banks. } \\
\text { Reduces vegetation: nitigate by } \\
\text { adding logs and/or revegetating. } \\
\text { You must consult with goverument } \\
\text { agencies if considering riprap. }\end{array}$ & Very stable banks. & $\begin{array}{l}\text { Permanent loss of riparian } \\
\text { habitat: may increase } \\
\text { velocity and downstream } \\
\text { erosion. }\end{array}$ & $\begin{array}{l}\text { Moderate to high, } \\
\$ 40-\$ 60 / \text { foot, } \\
\text { depending on local } \\
\text { availability of rock. }\end{array}$ \\
\hline \multicolumn{4}{|l|}{ Deflector Structures } \\
\hline $\begin{array}{l}\text { Jetties and barbs, usually } \\
\text { constructed with natural materials, } \\
\text { redirect water from unstable banks. } \\
\text { Not recommended for everyday } \\
\text { bank erosion problems. You must } \\
\text { consult with government agencies } \\
\text { if considering deflectors. }\end{array}$ & $\begin{array}{l}\text { When well designed, } \\
\text { provides long-term stability. }\end{array}$ & $\begin{array}{l}\text { Difficult to design and } \\
\text { install; may cause new } \\
\text { problems; unnatural } \\
\text { appearance. }\end{array}$ & $\begin{array}{l}\text { Moderate to high, } \\
\$ 100-\$ 1,000 \text { per } \\
\text { structure. }\end{array}$ \\
\hline \multicolumn{4}{|l|}{ Revetments } \\
\hline $\begin{array}{l}\text { Organic version of riprap using } \\
\text { bundles of brush, roots, or trees. } \\
\text { Tires, cars, and other debris are } \\
\text { prohibited as bank protection. }\end{array}$ & $\begin{array}{l}\text { Uses natural materials: easy } \\
\text { to install. }\end{array}$ & $\begin{array}{l}\text { Not effective in high-energy } \\
\text { streams. Results take time. }\end{array}$ & $\begin{array}{l}\text { Moderate, } \\
\$ 5-\$ 25 / \text { foot. }\end{array}$ \\
\hline \multicolumn{4}{|l|}{ Channel Realignment } \\
\hline $\begin{array}{l}\text { To restore natural functions. } \\
\text { Extrcme measure; requires careful } \\
\text { consideration. }\end{array}$ & $\begin{array}{l}\text { Quickest recovery to full } \\
\text { potential; replaces all } \\
\text { functions. }\end{array}$ & $\begin{array}{l}\text { High cost; must use } \\
\text { professional. }\end{array}$ & $\begin{array}{l}\text { Moderate to high, } \\
\$ 10-\$ 70 / \text { foot. }\end{array}$ \\
\hline
\end{tabular}

* NOTE: These costs are used for comparison only and will vary depending on actual circumstance. 
M ontanans recognize we have a rich natural resource in the state's streams. They provide water for us, for fish, for wildlife, and for plants. They also provide us, directly and indirectly; with jobs and recreation. We are also becoming swvare of the value of riparian. areas-lice areas adjacent to streams-10 the aquatic ecosystem.

This guide has introduced you to stream management by emphasizing the importance of understanding the resource and preventing problems. First, the guide discussed the various stream types in Montana and their adjacent components such as floodplains and riparian areas. Secondly, the guidle focused on how to design a successful stream management strateg.: Finally, the guide described specific problems, their causes, effects, and solutions.

As Chapter Three points out, the problems and solutions related to strean management can be relatively simple; they can also be quite complex. Use the resources listed in this guide to help you evaluate the streams under your care, to correct some of the problems, and to develop an effective stream managenent plan that will prevent future problems and protect this valuable resource.

Successful stream management will leave a legacy of healthy streanis to future generations of Montanans. 


\section{Aquifer}

Saturated zones of sand, gravel, fractured bedrock, or other material under the surface that has space between particles to hold water.

\section{Bankfull width}

Distance between average high water mark (HWM) on each side of stream. HWM is associated with slope or vegetation changes.

\section{Chanuel}

Stream bed.

\section{Channel shape}

Cross-section of a channel.

\section{Dezuatering}

Removal of part or all of the water from streams or other bodies of water.

\section{Epheneral strean}

Flows for brief periods of time as a result of snowmelt or rainstorms.

\section{Floodplain}

Land next to stream where water overflows during floods.

\section{Gradient}

Steepness or fall of slope.

\section{Habitat}

Food, water, shelter, and space that an animal requires.

\section{Intermittent streanu}

Flows only certain times of the year with water from springs or runoff.

\section{Lateral erosion}

Where a stream erodes its banks and ultimately widens the stream channel.

\section{Meandering}

Highly sinuous stream, frequently winding back and forth across the valley floor.

Non-point source pollution Water pollutants originating from dispersed areas, such as erosion of disturbed soils.

\section{Perennial stream}

Flows all year.

\section{Point bar}

Deposit formed on the inside bend of a stream.

\section{Point source pollution}

Water pollutants originating from a known point, such as a discharge pipe.

\section{Pool}

Deeper portions of the stream channel caused by increased scouring on the outside of turns.

\section{Reach}

Length of stream with similar characteristics, selected for study or observation.

\section{Revetuient}

Installation of materials such as trees, boards, etc., that dissipate or deflect the stream's energy and protect banks from lateral erosion.

\section{Riffle}

Shallow water with rapid current and flow broken by a substrate of gravel.

\section{Riparian areas}

Lands adjacent to streams and rivers where the vegetation is influenced by the greater availability of water.

\section{Runoff}

Movement of water over earth's surface.

\section{Sinuosity}

Amount of curvature in stream channel.

\section{Watershed}

Total land area that drains water to a given point; includes all area drained by one stream. 


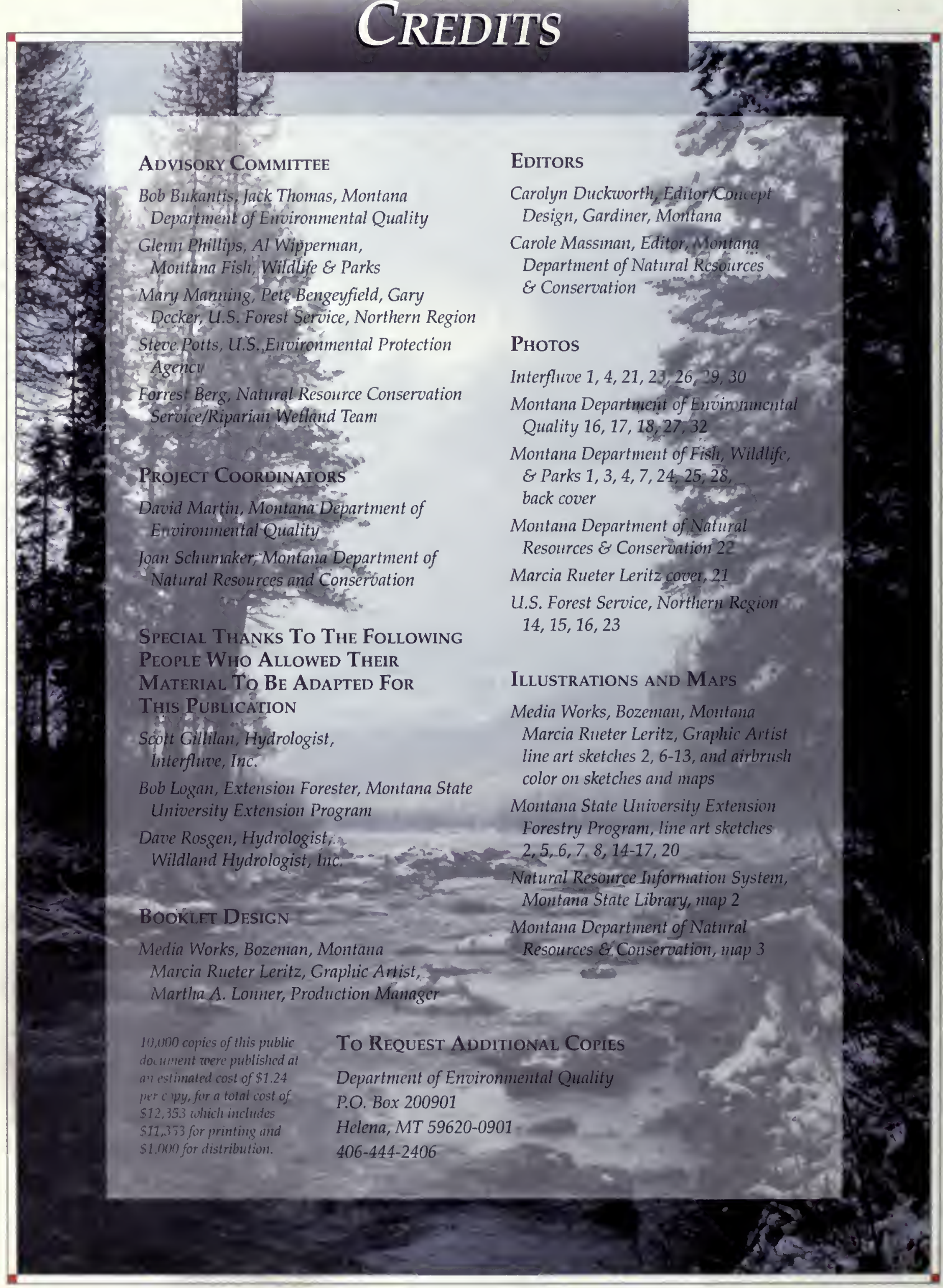

